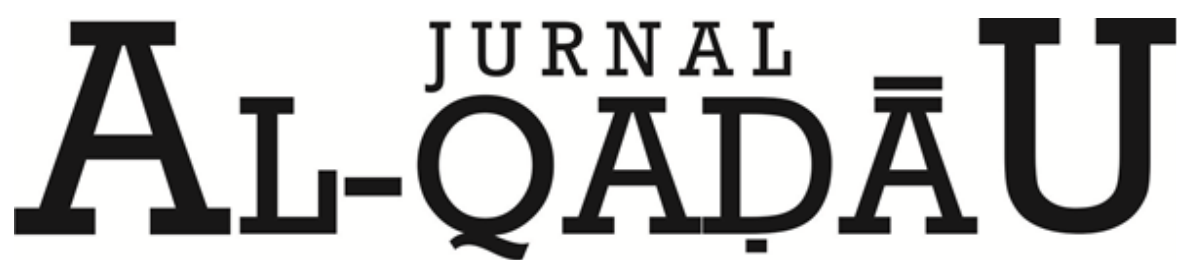 \\ PERADILAN dan HUKUM KELUARGA ISLAM
}

\section{Hibah dalam Perspektif Sunnah Nabi}

Grant in the Perspective of the Sunnah of the Prophet

Subehan Khalik

Dosen Fakultas Syariah dan Hukum UIN Alauddin Makassar

Email : subehank1@gmail.com

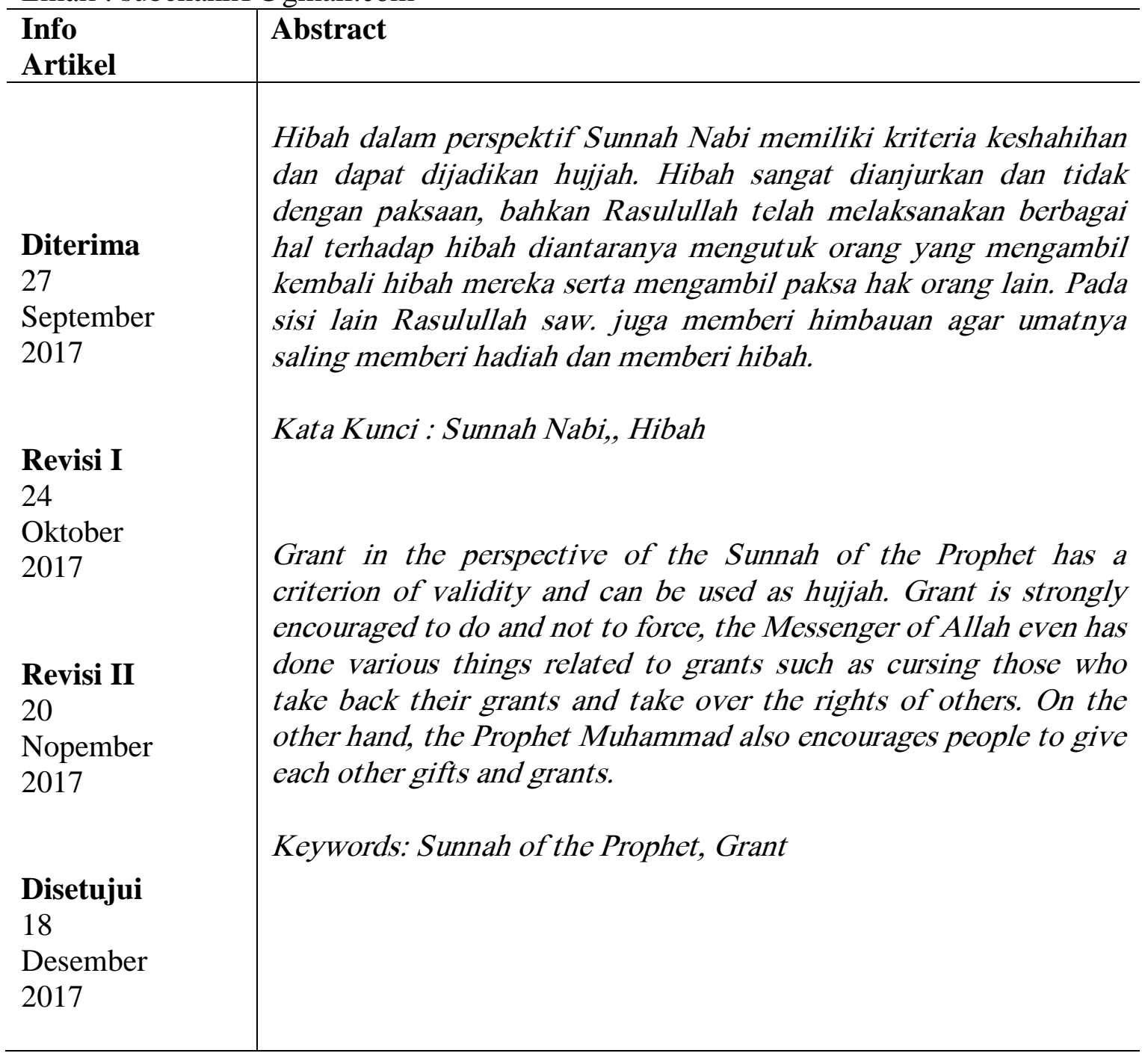




\section{A. Latar Belakang Masalah}

Hibah merupakan salah satu bentuk perpindahan harta dari seseorang ke orang lain secara sukarela dan tanpa paksaan. Hibah merupakan salah bentuk pemberian tanpa pamrih dan masuk dalam kategori perbuatan hukum bersegi satu. Hibah merupakan salah satu bentuk pengaturan harta dari segi perpindahannya yang diatur oleh syara' meskipun perbutan tersebut tidak berdampak kepada siapapun.

Rasulullah saw. telah mengatur beberapa hal berkaitan dengan pemberian hibah kepada seseorang untuk menjadi rambu bahwa perbuatan tersebut mutlak diatur meski sifatnya tidak memberi dampak kepada siapapun. Dikatakan demikian, sebab hibah merupakan perbuatan hukum biasa dengan sukarela untuk memberi sejumlah barang kepada orang lain. Ketersediaan aturan terhadap perbuatan hibah hampir sama posisinya dengan pengaturan sesuatu yang mubah dalam hukum Islam. Sesuatu yang mubah masih tetap dijadikan sebagai bahan hukum untuk melindungi agar perbuatan mubah tidak menjadi liar sebagaimana halnya dengan hibah.

\section{B. Permasalahan}

Bertitik tolak dari latar belakang masalah di atas, makalah ini akan membahas secara konfrehensif tentang Bagaimana bentuk dan validitas hadis tentang hibah, dengan sub masalah sebagai berikut:

1. Bagaimana Hadis Nabi tentang hibah dari aspek keadilan dalam persaksian, pengembalian, dan perampasan

2. Bagaimana tingkat validitas hadis yang mengatur hibah dalam Hadis Nabi.

\section{PEMBAHASAN}

\section{A. Hadis-Hadis Nabi Tentang Hibah dan Pengelompokan Topiknya}

Menggunakan kitab miftāh kunūz al-sunnah penulis telah menelusuri 68 hadis Nabi tentang hibah. Hadis-hadis tersebut ditelusuri dengan menggunakan term هبة - إنتهب -

1 Meskipun dalam kitab Miftāh Kunūz al-Sunnah terdapat anjuran untuk menggunakan term dalam menelusuri hibah dalam hadis Nabi, namun penulis urung menggunakan anjuran tersebut mengingat kandungan makna dalam term-term dimaksud akan menyebabkan perluasan 
memperhitungkan terjadinya pengulangan redaksional, maka hadis-hadis yang dapat ditampilkan berdasarkan topik bahasannya sebagai berikut:

1. Hadis-hadis Nabi tentang perlakuan terhadap barang hibah

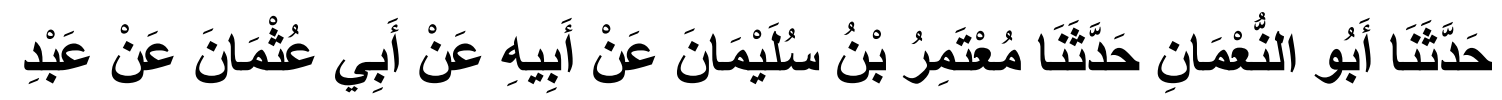

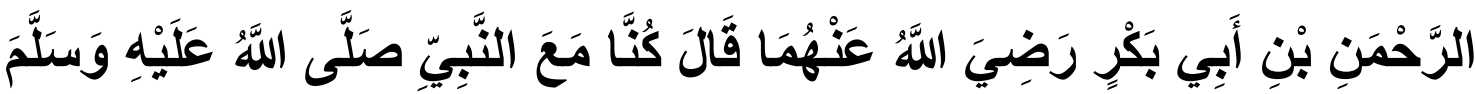

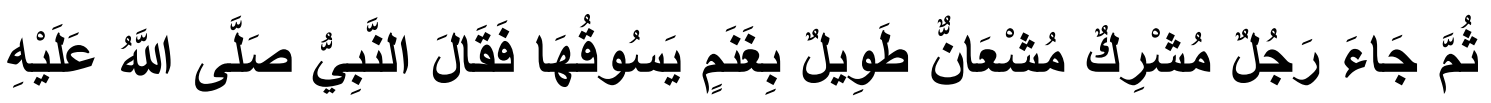

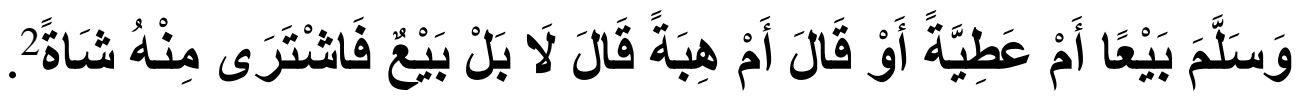

Artinya:

Telah menceritakan kepada kami Abu An-Nu'man telah menceritakan kepada kami Mu'tamir bin Sulaiman dari Bapaknya dari Abu 'Utsman dari 'Abdurrahman bin Abu Bakar radliallahu 'anhuma berkata: "Kami pernah bersama Nabi shallallahu 'alaihi wasallam tiba-tiba datang seorang lelaki musyrik dengan rambut panjang yang kusut dengan menggiring kambing. Maka Nabi shallallahu 'alaihi wasallam bertanya: "Apakah untuk dijual atau diberikan?" Atau sabdanya: "Atau dihibahkan?" Orang itu menjawab: "Bukan, tapi untuk dijual". Lalu Beliau shallallahu 'alaihi wasallam membeli seekor kambing darinya. ${ }^{3}$

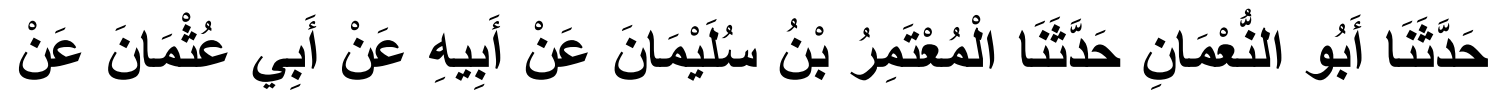

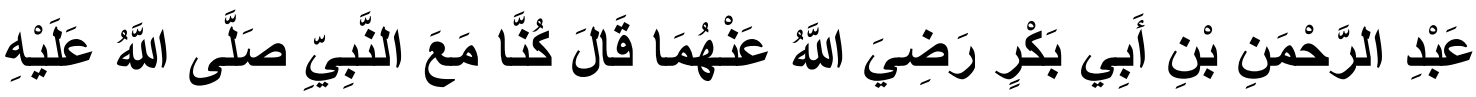

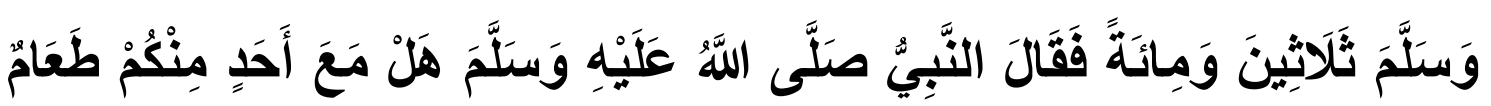

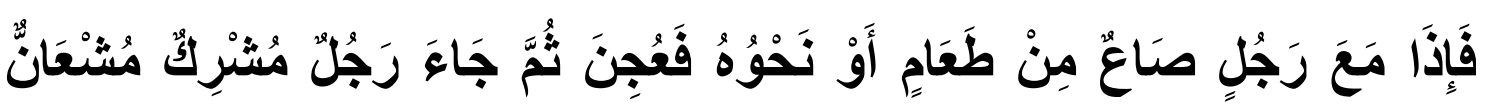

makna hibah dari konsep yang difahami bersama lewat pendekatan fikih. Namun demikian ada titik pertemuan makna pada saat hadis hibah yang berbicara tentang pemberian kepada istri, mengalami persamaan makna dengan șadukah dalam perkawinan. Selanjutnya lihat Muhammad Fuā'd 'Abd al-Bāqi, Miftāh Kunūz al-Sunnah, (Lahore; Idārah Tajumān al-Sunnah, 1978), h. 513.

2 Abū 'Abdullāh Muḥammad bin Ismā’̄il bin Ibrāḥim Ibn al-Mugīrah bin Bardizbat alBukhārīy, Șaḥịh al-Bukhārīy, juz II (t.t. Dār Maṭba’ah al-Syabi, t.th), h. 772.

${ }^{3}$ Terjemahan Penulis 


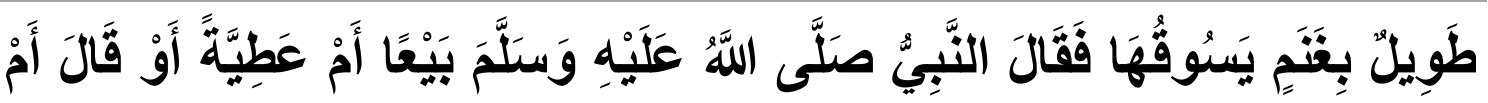

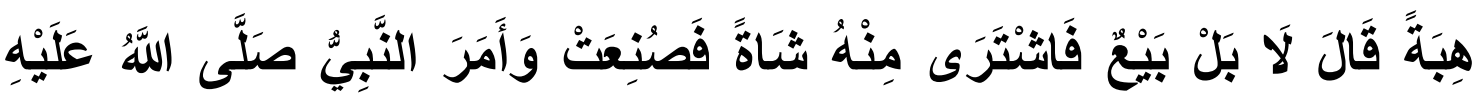

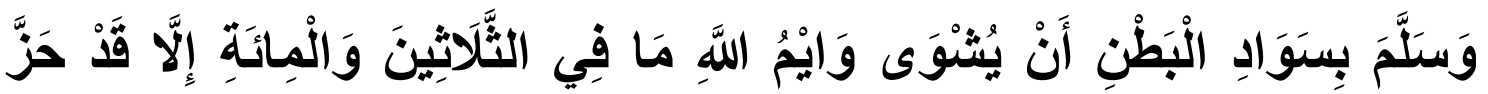

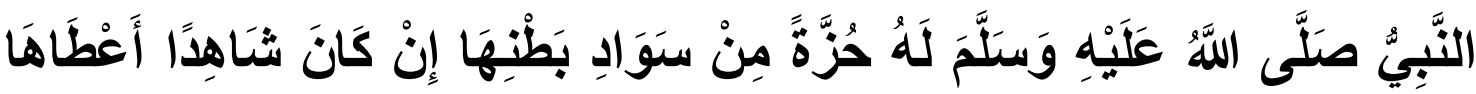

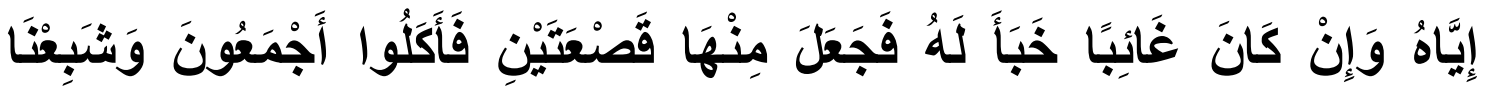

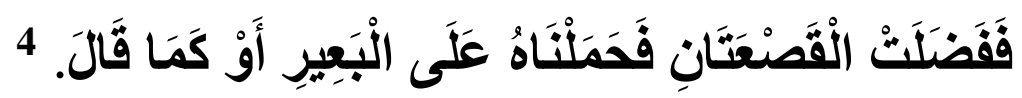

Artinya:

Telah menceritakan kepada kami Abu An Nu'man telah menceritakan kepada kami Al Mu'tamir bin Sulaiman dari bapaknya dari Abu 'Utsman dari 'Abdurrahman bin Abu Bakar radliallahu 'anhuma berkata; "Kami pernah bersama Nabi shallallahu 'alaihi wasallam (dalam perjalanan) berjumlah seratus tiga puluh orang lalu Beliau berkata: "Apakah diantara kalian yang memiliki makanan?" Maka jika ada sebanyak satu sha'makanan atau sejenisnya, dibuatlah adonan. Kemudian datang seorang musyrik yang berambut panjang namun agak semrawut membawa kambing yang digiringnya. Nabi shallallahu 'alaihi wasallam berkata: "Apakah kambing ini untuk dijual atau untuk dihadiahkan?" atau Beliau berkata dengan redaksi: "Atau dihibahkan?" Orang itu menjawab: "Tidak, tapi untuk dijual". Maka Beliau membeli seekor darinya". Lalu kambing itu dimasak dan Nabi shallallahu 'alaihi wasallam memerintahkan agar hatinya dibagi-bagikan. Demi Allah, tidak ada dari kami yang berjumlah seratus tiga puluh orang melainkan telah diberikan oleh Nabi saw. potongan jantung dari isi perut kambing tersebut. Jika ada yang hadir disitu, musti diberi, dan jika sedang tidak ada, disisakan baginya. Maka dibuat dalam dua kuali, lalu mereka makan semuanya dan kami merasa kenyang dan masih tersisa dua kuali lalu kami bawa diatas unta, atau sebagaimana dikatakannya". 5

4 Abū 'Abdullāh Muḥammad bin Ismā'īl bin Ibrāḥim Ibn al-Mugīrah bin Bardizbat alBukhārīy, Saḥ̄ḥ al-Bukhārīy, juz II, h. 923.

${ }^{5}$ Terjemahan Penulis 
2. Azas keadilan dalam hibah serta mempersaksikannya

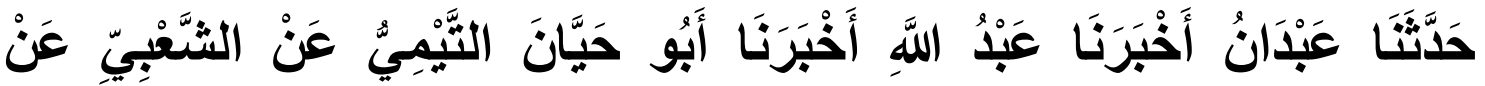

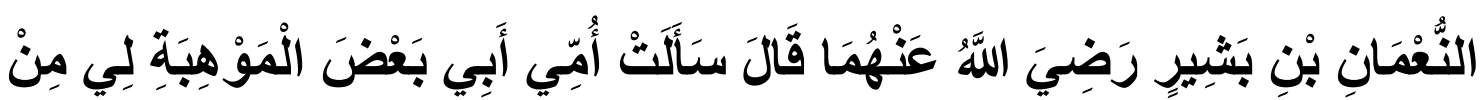

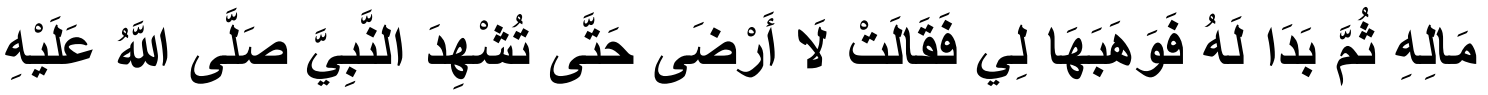

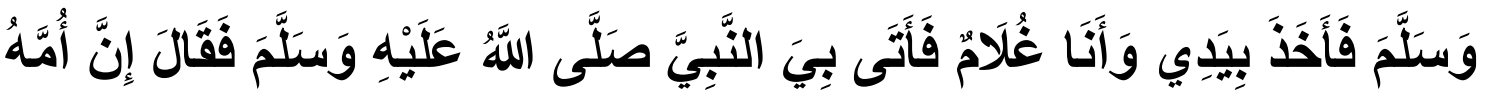

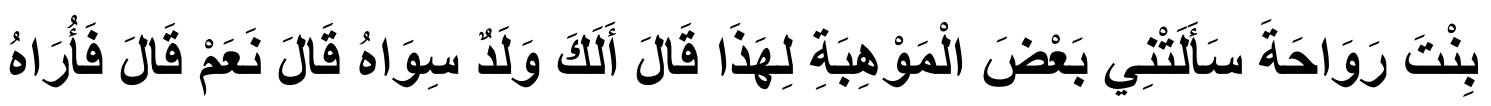

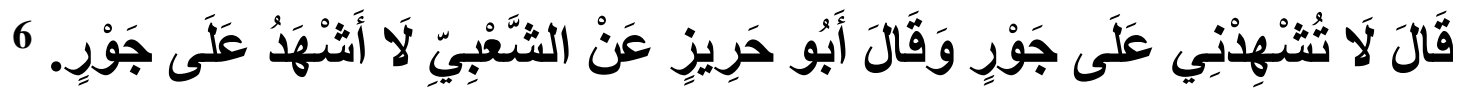

Artinya:

Telah menceritakan kepada kami 'Abdan telah mengabarkan kepada kami 'Abdullah telah mengabarkan kepada kami Abu Hayyan an-Taimiy dari Asy-Sya'biy dari An Nu'man bin Basyir radliallahu 'anhuma berkata: "Ibuku bertanya bapakku perihal sebagian pemberiannya kepadaku dari hartanya kemudian dia ingin memberikannya semua kepadaku, maka ibuku berkata: "Aku tidak rela sampai kamu persaksikan kepada Nabi shallallahu 'alaihi wasallam. Maka ayahku membawaku, saat itu aku masih kecil, menemui Nabi shallallahu 'alaihi wasallam lalu berkata: "Sesungguhnya ibunya, binti Ruwahah, bertanya kepadaku tentang sebagaian pemberianku kepada anak ini". Beliau bertanya: "Apakah kamu memiliki anak selain dia ini". Bapakku menjawab: "Ya punya". Dia berkata: "Aku menduga Beliau bersabda: "Janganlah engkau ajak aku dalam persaksian yang curang". Dan berkata, Abu Hariz dari Asy Sya'biy: "Aku tidak mau bersaksi diatas kecurangan". ${ }^{7}$

3. Larangan mengambil kembali hibah yang telah diberikan

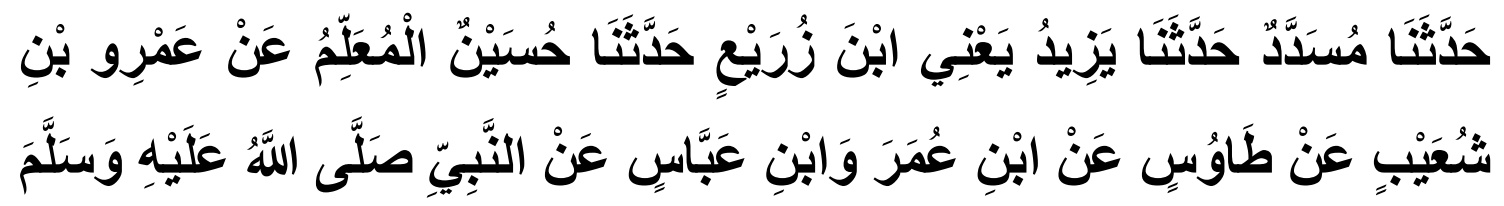

${ }^{6}$ Abū 'Abdullāh Muhammad bin Ismā'̄̄l bin Ibrāḥim Ibn al-Mugīrah bin Bardizbat alBukhārīy, Șahīh al-Bukhārīy, juz II, h. 945.

${ }^{7}$ Terjemahan Penulis 


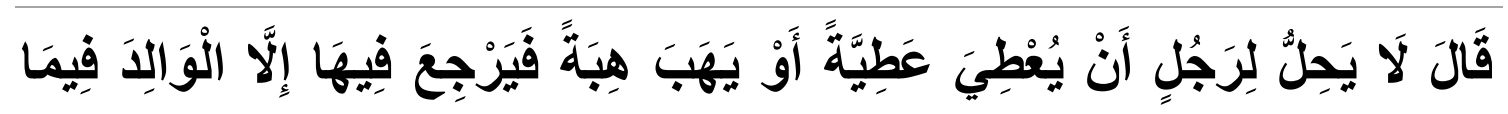

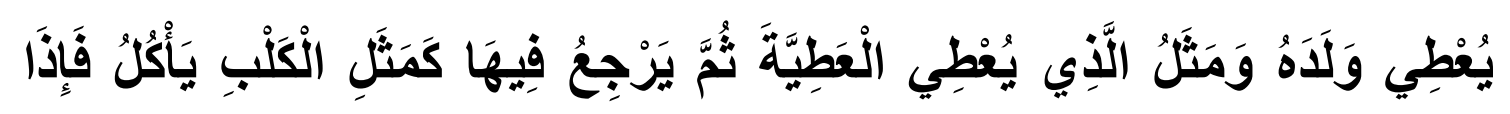

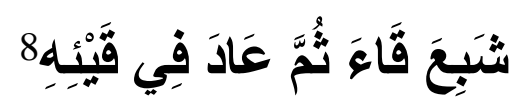

Artinya:

Telah menceritakan kepada kami Musaddad telah menceritakan kepada kami Yazid bin Zurai' telah menceritakan kepada kami Husain Al Mu'allim dari 'Amru bin Syu'aib dari Thawus dari Ibnu Umar dan Ibnu Abbas dari Nabi shallallahu 'alaihi wasallam, beliau bersabda: "Tidak halal bagi seorang laki-laki yang memberi suatu pemberian kemudian mengambilnya kembali, kecuali orang tua mengambil apa yang ia berikan kepada anaknya. Dan permisalan orang yang memberi suatu pemberian kemudian mengambilnya seperti anjing yang makan, maka setelah kenyang ia muntah kemudian menelan muntahannya kembali."

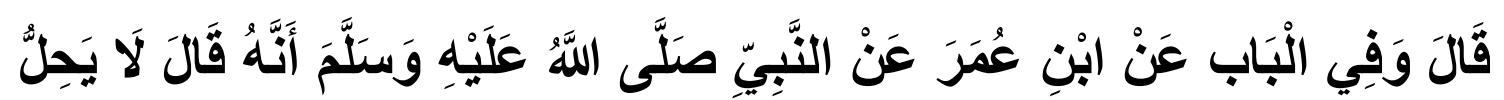

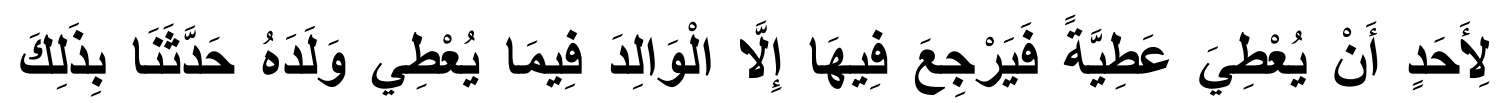

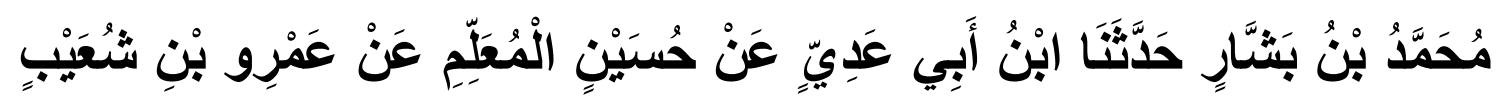

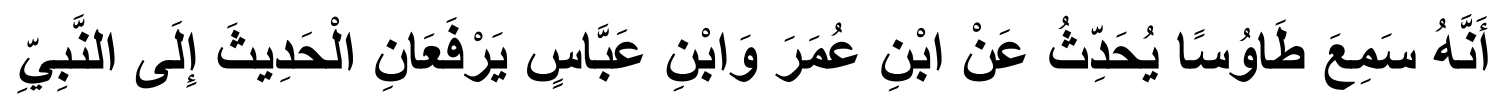

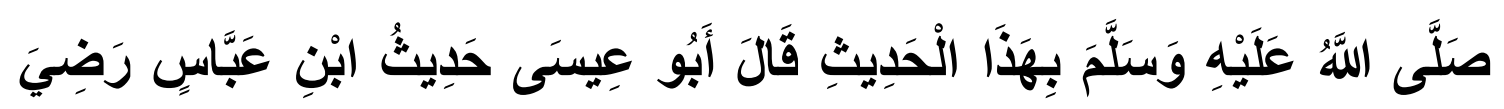

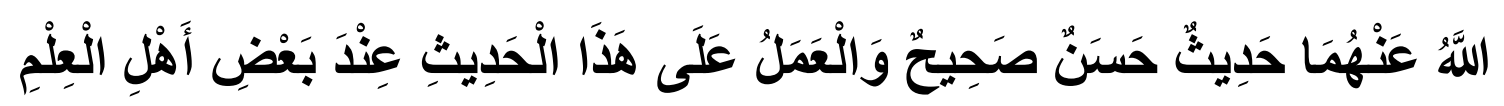

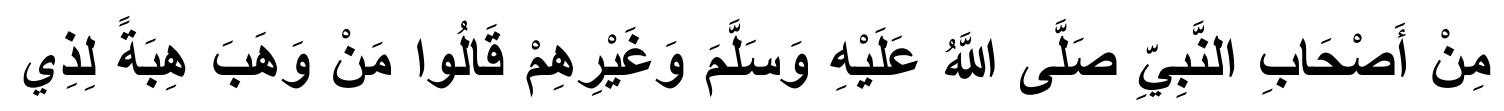

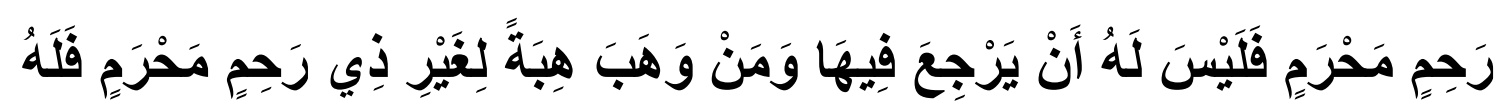

${ }^{8}$ Abū Dāwud Sulaimān bin al-Asy'ab al-Sijistānīy, Sunan Abī Dāwud, Juz III, (t.tp.; Muhammad 'Alīy al-Sayyid Nasyr wa al-Tauzi', t.th.), h. 315.

${ }^{9}$ Terjemahan Penulis 


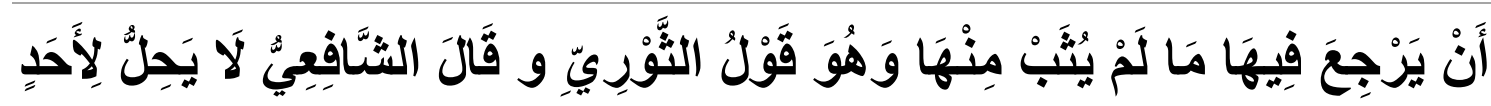

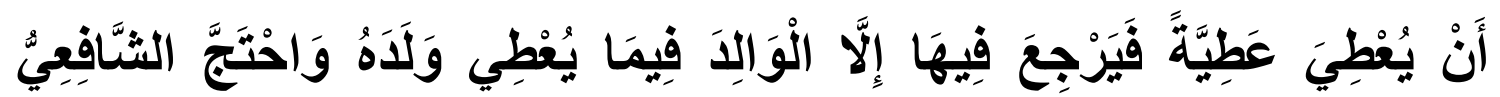

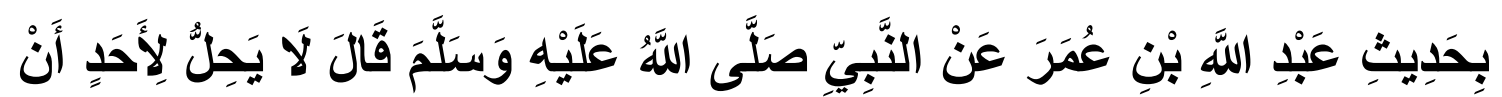

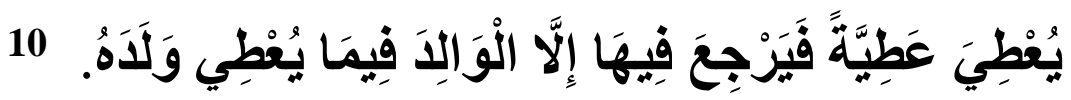

Artinya:

Ia mengatakan; Dalam hal ini ada hadits serupa dari Ibnu Umar dari Nabi shallallahu 'alaihi wasallam bahwa beliau bersabda: "Tidak halal bagi seseorang yang memberi suatu pemberian lalu menariknya kembali, kecuali orang tua yang telah memberi kepada anaknya." Telah menceritakan hal itu kepada kami Muhammad bin Basysyar telah menceritakan kepada kami Ibnu Abu 'Adi dari Husain Al Mu'allim dari Amr bin Syu'aib bahwa ia mendengar Thawus menyampaikan hadits dari Ibnu Umar dan Ibnu Abbas keduanya memarfu'kan hadits ini kepada Nabi shallallahu 'alaihi wasallam. Abu Isa berkata; Hadits Ibnu Abbas radliallahu 'anhuma adalah hadits hasan shahih dan hadits ini menjadi pedoman amal menurut para ulama dari kalangan sahabat Nabi shallallahu 'alaihi wasallam dan selain mereka. Mereka berpendapat; Barangsiapa yang memberikan sesuatu kepada kerabatnya, maka ia tidak berhak menarik kembali, namun barangsiapa memberikan sesuatu kepada selain kerabatnya ia boleh mengambilnya kembali, tetapi ia tidak mendapatkan pahala atas permberiannya tersebut. Ini adalah pendapat Ats Tsauri sedangkan Asy Syafi'i berpendapat; Tidak halal seseorang memberikan sesuatu lalu menarik kembali kecuali orang tua terhadap apa yang telah diberikan kepada anaknya, Asy Syafi'i berhujjah dengan hadits Abdullah bin Umar dari Nabi shallallahu 'alaihi wasallam, beliau bersabda: "Tidak halal seseorang memberikan sesuatu pemberian lalu menariknya kembali, kecuali orang tua (yang menarik pemberian atas) apa yang telah diberikan kepada anaknya.". ${ }^{11}$

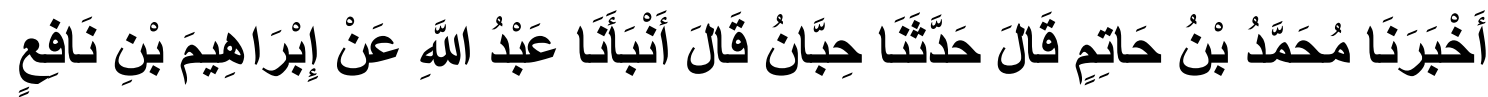

\footnotetext{
${ }^{10}$ Sunan Al-Turmūziy, Al-Jāmi‘ al-Șaḥịh, Juz V, (Beirūt: Dār al-Kutub al-‘Ilmiyyat, t.th.), h. 251.

${ }^{11}$ Terjemahan Penulis
} 


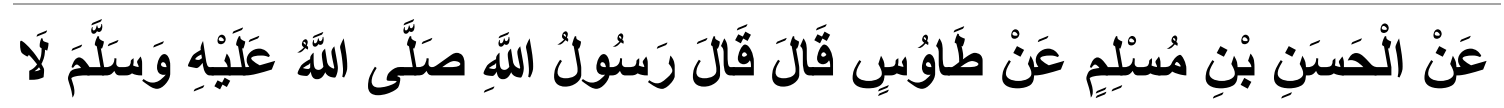

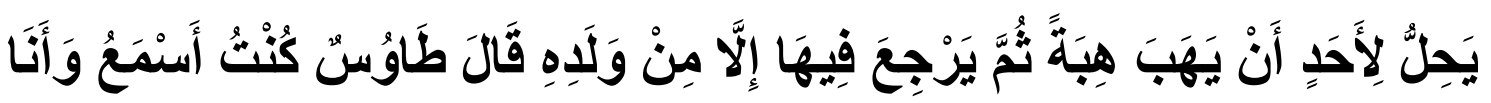

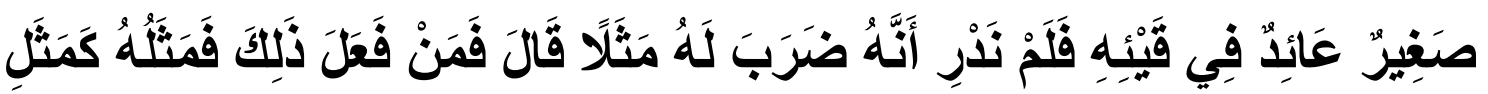

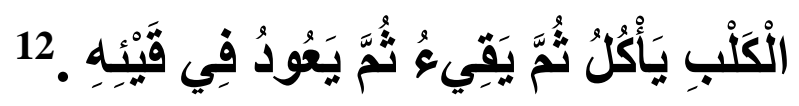

Artinya:

Telah mengabarkan kepada kami Muhammad bin Hatim berkata; telah menceritakan kepada kami Hibban berkata; telah memberitakan kepada kami Abdullah dari Ibrahim bin Nafi' dari Al Hasan bin Muslim dari Thawus berkata, "Rasulullah shallallahu 'alaihi wasallam bersabda: "Tidak halal bagi seseorang yang memberikan pemberian kemudian mengambilnya kembali kecuali dari orang anaknya sendiri." Thawus berkata, "Aku mendengar di saat masih kecil perkataan; 'orang yang kembali memakan muntahannya', aku tidak mengetahui bahwa beliau memberikan suatu permisalan." Beliau mengatakan: "Barangsiapa melakukan hal tersebut (mengambil kembali sesuatu yang telah diberikannya) maka permisalannya seperti anjing yang makan kemudian muntah, lalu ia makan kembali muntahannya."13

4. Kepemilikan hibah (mahar) yang diserahkan sebelum pernikahan

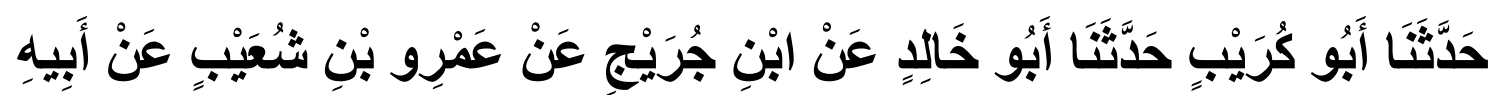

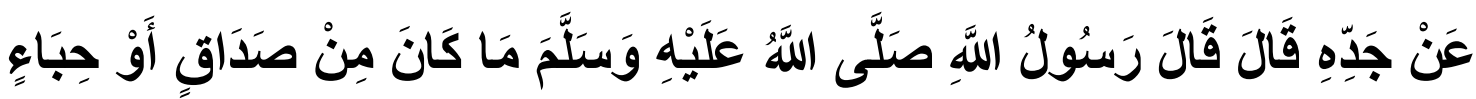

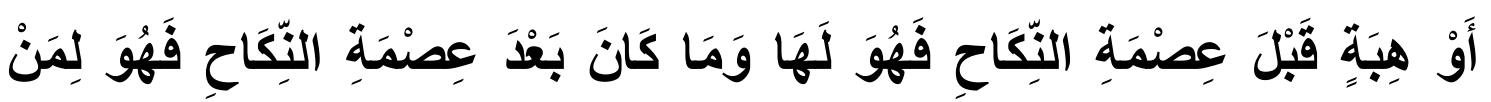

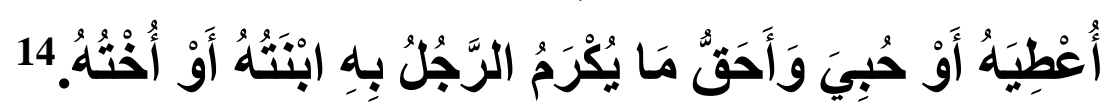

Artinya:

\footnotetext{
${ }^{12}$ Imam al-Nasāīy, Sunan al-Nasāīy, Juz XII (Beirūt: Dār al-Fikr, t.th.), h. 51.

${ }^{13}$ Terjemahan Penulis

${ }^{14}$ Sunan Ibn Mājah, Sunan Ibn Mājah, Juz 6, (Beirūt: Dār al-Fikr, t.th.), h. 172.
} 
Telah menceritakan kepada kami Abu Kuraib berkata, telah menceritakan kepada kami Abu Khalid dari Ibnu Juraij dari Amru bin Syu'aib dari Bapaknya dari Kakeknya ia berkata, "Rasulullah shallallahu 'alaihi wasallam bersabda: "Mahar, hadiah atau hibah yang diberikan sebelum akad nikah, maka itu semua adalah miliknya (isteri). Namun jika diberikan setelah akad nikah, maka itu semua adalah milik orang yang diberi, dan yang paling berhak untuk perioritaskan adalah anak perempuan atau saudara perempuannya." 15

5. Nabi tidak menerima hibah kecuali dari suku Quraisy, Anshar dan Ṡaqif

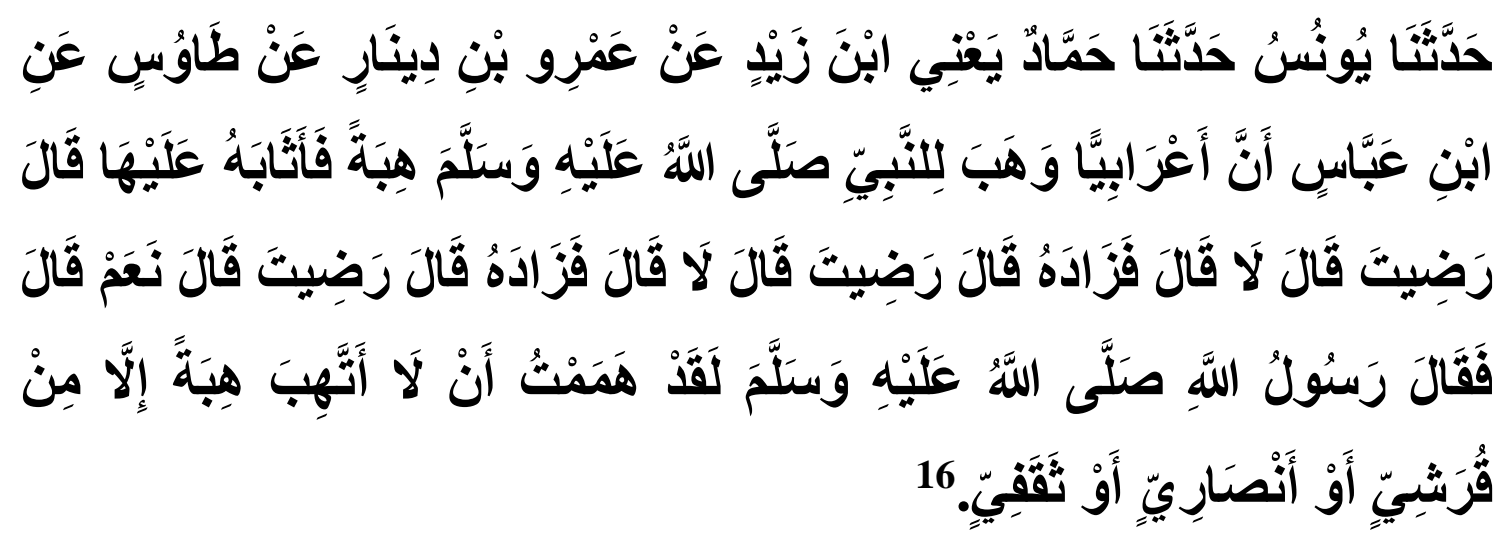

Terjemahan:

Telah menceritakan kepada kami Yunus telah menceritakan kepada kami Hammad yakni Ibnu Zaid, dari 'Amru bin Dinar dari Thawus dari Ibnu Abbas; bahwa seorang badui memberi sesuatu kepada Nabi shallallahu 'alaihi wasallam lalu beliau membalasnya, kemudian beliau bersabda: "Engkau rela?" ia menjawab. "Tidak." Beliau menambahinya lalu bersabda: "Engkau rela?" ia menjawab; "Tidak." Beliau menambahinya lagi lalu bersabda: "Engkau rela?" ia menjawab; "Ya." Kemudian Rasulullah shallallahu 'alaihi wasallam bersabda: "Sungguh aku sangat ingin untuk tidak menerima suatu pemberian kecuali dari orang Quraisy, Anshar atau Tsaqif."17

6. Larangan membegal (merampas harta milik orang lain)

\footnotetext{
15 Terjemahan Penulis.

${ }^{16}$ Aḥmad bin Ḥanbal, Musnad Aḥmad bin Hanbal, Juz IV (Beirūt: Dār al-Fikr, 1971), h. 424.

17 Terjemahan Penulis.
} 


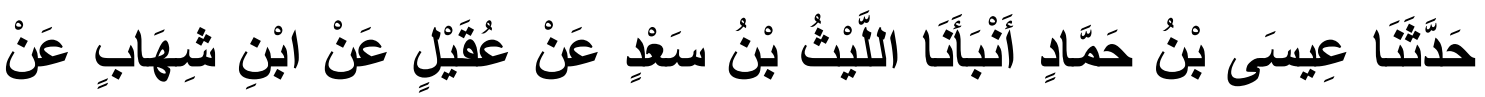

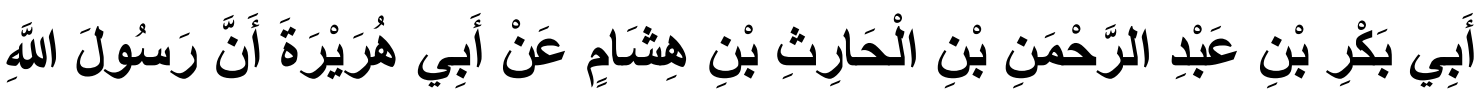

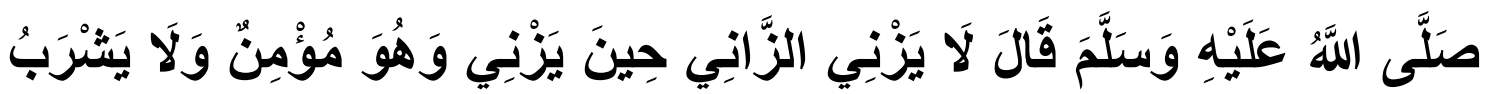

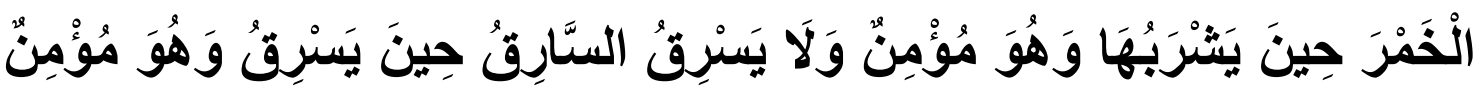

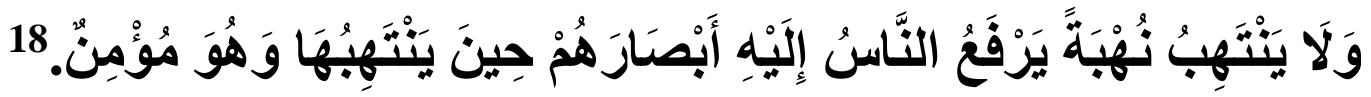
Artinya:

Telah menceritakan kepada kami Isa bin Hammad telah memberitakan kepada kami Al Laits bin Sa'd dari 'Uqail dari Ibnu Syihab dari Abu Bakar bin Abdurrahman bin Al Harits bin Hisyam dari Abu Hurairah, bahwa Rasulullah shallallahu 'alaihi wasallam bersabda: "Tidak disebut beriman orang yang berzina saat melakukannya, tidak disebut mukmin orang yang minum khamer saat melakukannya, tidak disebut mukmin orang yang mencuri saat melakukannya. Dan tidaklah orang yang merampas harta orang lain hingga membuat pandangan orang tertuju padanya disebut sebagai mukmin saat melakukannya."19

7. Anjuran Nabi untuk saling memberi hadiah

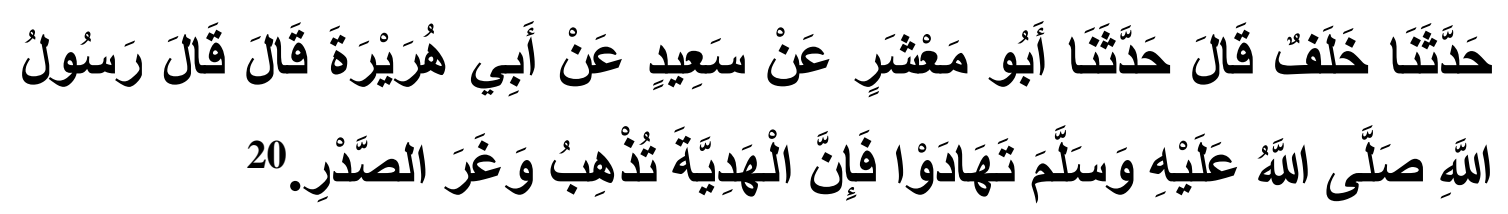

Artinya:

Telah menceritakan kepada kami Khalaf berkata; telah menceritakan kepada kami Abu Ma'syar dari Sa'id dari Abu Hurairah berkata; Rasulullah shallallahu 'alaihi wasallam bersabda: "Hendaklah kalian saling memberi hadiah, karena hadiah dapat menghilangkan kebencian hati. "21

\footnotetext{
${ }^{18}$ Sunan Ibn Mājah, Sunan Ibn Mājah, Juz 6, h. 175.

19 Terjemahan Penulis.

${ }^{20}$ Aḥmad bin Ḥanbal, Musnad Aḥmad bin Ḥanbal, Juz V(Beirūt: Dār al-Fikr, 1971), h. 244.

${ }^{21}$ Terjemahan Penulis
} 


\section{B. Kritik Sanad dan Matan Hadis}

Kritik sanad adalah sebuah upaya ilmiyah untuk mengadakan penelitian terhadap para periwayat hadis. Upaya ini diawali dengan melakukan I'tibār. ${ }^{22}$ Dimaksudkan untuk menemukan apakah dalam riwayat ini ada syahīd atau mutābi ${ }^{23}$ Pada bagan hadis terlihat bahwa para periwayat hadis menggunakan metode periwayatan yang beragam. sebagaimana tergambar dari sigat al-tahammul yang mereka gunakan meliputi; haddasana,' 'an, dan qāla.

Secara garis besar hadis-hadis tentang kambing yang dipertanyakan oleh Rasulullah saw. keberadaannya melewati tiga jalur periwayatan yang melalui masingmasing Bukhari, Muslim dan Ahmad bin Hanbal. Jalur-jalur yang melalui Bukhari dan Ahmad bin Hanbal tidak terdapat mutābi' sebagaimana jalur Muslim.

Jalur-jalur dimaksud sebagai berikut:

${ }^{22}$ Menurut bahasa, arti al-i'tibār ialah peninjauan terhadap berbagai hal dengan maksud untuk dapat diketahui sesuatunya yang sejenis. Menurut istilah ilmu hadis, al-i'tibār berarti menyertakan sanadsanad yang lain untuk suatu hadis tertentu, yang hadis itu pada bagian sanadnya tampak hanya terdapat seorang periwayat saja; dan dengan menyertakan sanad-sanad yang lain tersebut akan dapat diketahui apakah ada periwayat yang lain ataukah tidak. Lihat, Mahmūd Ṭạ̣hān, Taysir Mustalah al-Hadīs. (Beirūt: Dār al-Qur'ān al-Karīm, 1979 M), h. 140; Ibnu Hajr al-`Asqalaniy, Nuzhat al-Nazar Syarh Nukhbat al-Fikr (Kairo: Maṭba’at Istiqāmah, 1368 H.), h. 23; Abu `Amr 'Uṡmān ibn’ Abd al-Raḥmān ibn al-Șalah al-Syahrazūriy, 'Ulūm al-Hadiś (al-Madinat al-Munawwarah: al-Maktabat al-`Ilmiyyah,1972 M.), h. 74-75.

${ }^{23}$ Menurut istilah ulama hadis, syāhid ialah hadis yang diriwayatkan oleh seorang sahabat sama dengan hadis yang diriwayatkan oleh sahabat yang lain, secara lafal dan atau secara makna. Sedangkan $m u t a \overline{b i}$ ' ialah berserikatnya seorang periwayat dengan yang lain tentang suatu riwayat (hadis) dari seorang guru yang terdekat tetapi tidak sampai pada tingkat sahabat (periwayat pertama). Lihat Muhammad 'Ajjaj al-Khatib, Usûl al-Hadîs 'Ulumuhu wa Mustalahuhu (Beirut: Dar al-Fikr, 1409 H./1989 M.), h. 366-67; Muhammad al-Sabbag, al-Hadis al-Nabawiy (T.t.: al-Maktab al-Islamiy, 1392 H./ 1972 M.), h. 188-89; Mahmud al-Tahhan, "Taysîr",h. 140-42. Jadi dapat dinyatakan bahwa syahid ialah hadis yang diriwayatkan oleh lebih dari satu dan terletak pada tingkat sahabat. Sedangkan mutâbi` ialah hadis yang diriwayatkan oleh lebih dari satu orang dan terletak bukan pada tingkat sahabat Nabi. 
Subehan Khalik

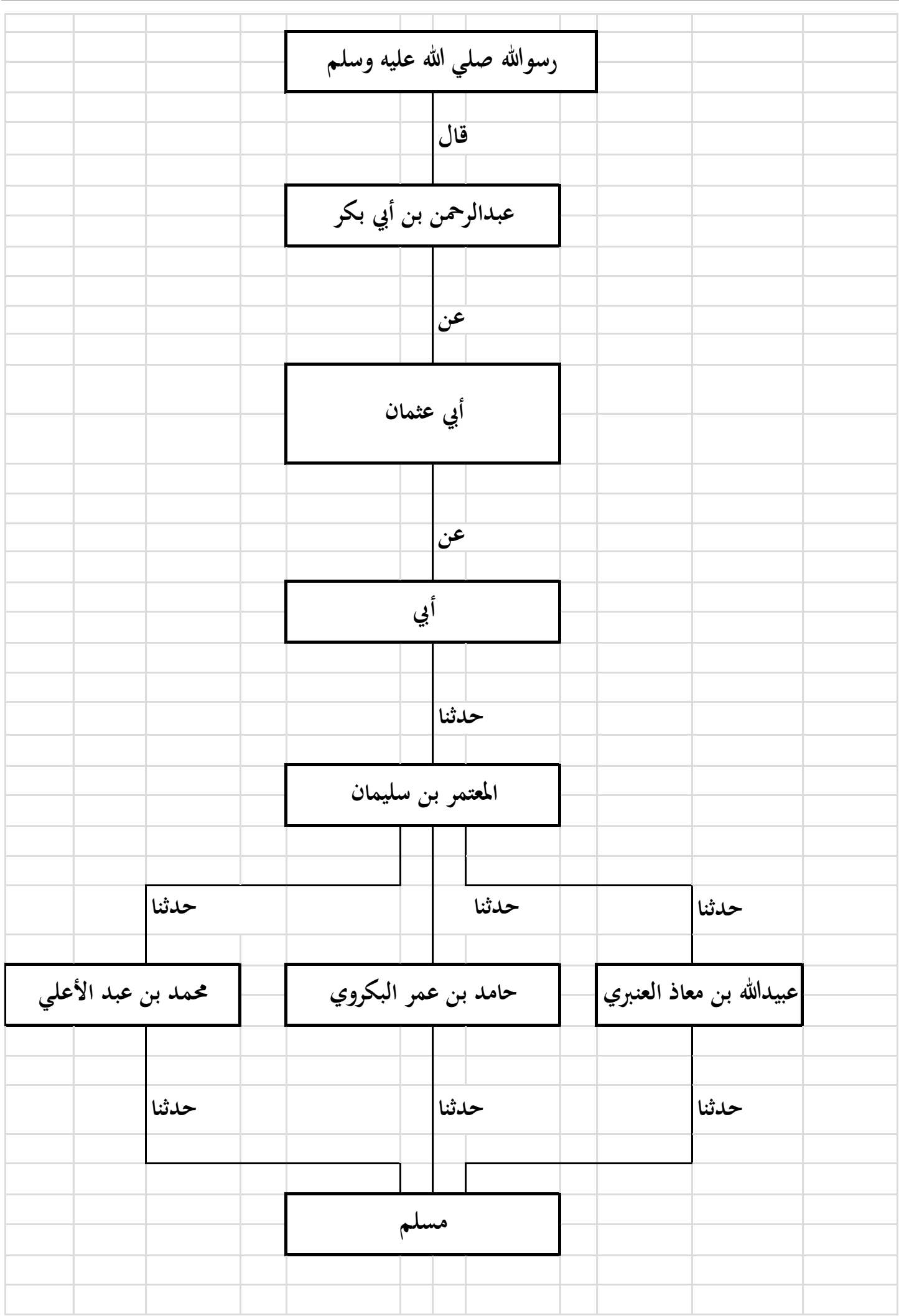

Pada skema terdepan terlihat bahwa jalur Muslim yang terpilih menjadikan 'Abd al-Raḥmān bin Abī Bakr selaku periwayat I sanad ke 6, Abū Us̉mān selaku periwayat II 
sanad ke 5, Abī (akan diungkap identitas pada saat kritik sanad) selaku periwayat ke III dan sanad ke 4, al-Mu'tamir bin Sulaimān selaku periwayat ke IV dan sanad ke 3, Ḥāmid bin Umar al-Bakrawīy selaku periwayat ke V dan sanad ke 2 serta Imam Muslim selaku periwayat ke VI dan sanad Pertama. Sebagaimana terlihat dalam diagram, masing-masing periwayat dalam ketersambungan sanadnya menggunakan sigat altahammul ${ }^{24}$ masing-masing; haddasianā, 'an dan qāla.

Terlihat pula pada uturan periwayat ke $\mathrm{V}$ sanad ke 2 terjadi corrabotartion atau mutābi' antara tiga periwayat yaitu; 'Ubaidillāh bin Mu'āz al-'Anbarīy; Hāmid bin 'Umar al-Bakrawīy dan Muḥammad bin 'Abd al-A'lā. Dalam versi Muslim ketiga periwayat ini telah saling menguatkan.

Berikut ini diuraikan biografi singkat serta penilaian kritikus hadis terhadap masing-masing tokoh yang terlihat dalam diagram I di depan yaitu;

1. Imam Muslim, Bernama Muslim bin al-Ḥajjāj bin Muslim al-Qusyairīy Abū alHusain al-Naysabūrīy al-Hafiz ${ }^{25}$ (Lahir Tahun 206 H dan Wafat pada hari ahad 261 H diusia 55 Tahun). ${ }^{26}$

Guru dari Imam Muslim cukup banyak, diantaranya adalah; al-Qa'bīy, Aḥmad bin Yūnus, Ismail bin Abīy Urays, Dāwud bin 'Amr al-Ḍabbīy, Sa'̄̄d bin Manșūr, Syaibān bin Farūkh serta beberapa banyak lagi guru lainnya ${ }^{27}$

Murid-murid yang menerima hadis dari Imam Muslim adalah sebagai berikut; alTurmuzi, Muhammad bin 'Abd al-Wahhab al-Farra', 'Ali bin al-Husain al-Junaid, Ibnu Khuzaimah, Ibn Sā’id, al-Sarrāj, Abū Muḥammad bin Ab̄̄y Ḥātim al-Rāzīy. ${ }^{28}$

\footnotetext{
${ }^{24}$ Adalah lambang-lambang yang digunakan oleh para periwayat dalam hubungan periwayatan dan penerimaan hadis. Lihat, M. Syuhudi Ismail, Kaedah Kesahihan Sanad Hadis; Telaah Kritis dan Tinjauan dengan Pendekatan Ilmu Sejarah (Jakarta: Cet. I; Bulan Bintang, 1988), h. 51.

${ }^{25}$ Ibnu Hajar al-‘Asqalānīy, Tahzīb al-Tahzīb, Juz I, (t.tp. Muassah al-Risālat, t.th), h. 67.

${ }^{26}$ Ibnu Hajar al-`Asqalānīy, Tahzīb al-Tahzīb, Juz I, h. 68

${ }^{27}$ Ibnu Hajar al-‘Asqalānīy, Tahzīb, Juz I, h. 67.

${ }^{28}$ Ibnu Hajar al-`Asqalānīy, Tahzīb, Juz I, h. 67.
} 
Imam Muslim dinilai siqqah dan termasuk dalam kategori Huffāz yang memiliki kedalalamn pengetahuan terhadap hadis. ${ }^{29}$

2. Muḥammad bin 'Abd al-A'lā. Ia adalah Muḥammad bin 'Abd al-A'lā al-Ṣan'ānīy al-Qaysīy, dikenal pula dengan nama Abū 'Abdullah al-Bașrīy. ${ }^{30}$

Gurunya adalah; Ismā’il bin 'Ulaiyah, Ummiyah bin Khālid, Khālid Ibn al-Ḥaris̀, Sufyān bin Uyainah, Salamah bin Raja', 'Abd al-Rahmān bin Mahdi, 'Abd alRazzāq bin Hammām, Imrān bin Uyainah. ${ }^{31}$

Muridnya-muridnya; Abū Dāwud, Ibrāḥīm bin 'Abdullāh al-'Askarīy al-Zabīybīy, Ibrāḥīm ybin Yūsuf bin Nukhrah bin al-Ḥasan al-Ṣan’ānīy, Abū Bakar Aḥmad bin ‘Amru bin Abīy ‘Āṣim, Baqīy bin Makhlad al-Andalūsīy, Ja'far bin Muḥammad alFiryābīy ${ }^{32}$

Para kritikus memberi penilaian kepada Muḥammad bin 'Abd al-A'lā sebagai berikut; Abū Zur'ah dan Abū Ḥātim menilai; siqah, Ibnu Ḥibbān juga menyebut figur ini dalam kitab "al-Siqqāt”, Sementara itu Imam Bukhārīy menjelaskan bahwa figure ini wafat pada tahun $245 \mathrm{H}$. di Basrah. ${ }^{33}$

3. Mu’tamir bin Sulaimān bin Turkhān (wafat $187 \mathrm{H}$ ). Kunniyahnya adalah Abū Muhammad al-Bașrīy. ${ }^{34}$

Gurunya adalah; Ibrāhim bin Yazīd al-Khużīy, al-Akhḍār bin Yazīd, Isḥāq bin Suwaidi al-‘Adawīy, Ismā’̄̄l bin Ḥammād, Ismā’ōl bin Khālid, Ayyāsy bin Dagfal, Burda bin Sinān al-Syāmmīy. ${ }^{35}$

29 Ab̄̄ Muḥammad 'Abd al-Rahmān bin Abīy Hātim Muhammad bin Idrīs bin Munzir alTamīymīy al-Hazalīy al-Rāzīy, Kitāb al-Jarh al-Ta'dīl, Jilid IV, (Beyrūt: Dār al-Kutub al-'Ilmiyyah, 1953), h. 181-182.

${ }^{30}$ Hajjāj bin Yūsuf al-Mazzi, Tahzib al-Kamāl fi Asma' al-Rijal, Jilid V, (Beirūt: Mu'assah alRisalah, 1997), h. 581.

${ }^{31}$ Hajjāj bin Yūsuf al-Mazzi, Tahzib al-Kamāl, h. 582.

${ }^{32}$ Hajjāj bin Yūsuf al-Mazzi, Tahzib al-Kamāl, h. 582

${ }^{33}$ Hajjāj bin Yūsuf al-Mazzi, Tahzib al-Kamāl, h. 583

${ }^{34}$ Hajjāj bin Yūsuf al-Mazzi, Tahzib al-Kamāl, Juz 28, h. 251

${ }^{35}$ Hajjāj bin Yūsuf al-Mazzi, Tahzib al-Kamāl, Juz 28, h. 251 
Muridnya adalah: Aḥmad bin Hanbal, Aḥmad bin 'Abdah al-Ḍabbīy, Abū alAsy’ab Aḥmad bin al-Miqdām al-'Ijlīy, Isḥaq bin Ibrāhim bin Ḥayba bin al-Syahị̂d, 36 Di mata kritikus periwayat hadis, al-Mu'tamir adalah seorang yang siqat sebagaimana ungkapan Isḥaq bin Manșūr, demikian juga pernyataan Yahyā bin Ma'īn serta Abū Hātim; siqat, șadūq. ${ }^{37}$ Al-Mu'tamir lahir pada tahun $106 \mathrm{H}$ dan wafat pada tahun $187 \mathrm{H}$ di Basrah pada masa pemerintahan Khalifah Harun alRasyid. ${ }^{38}$

4. Sulaimān bin Ṭurkhān, Kunniyahnya adalah Abū al-Mu'tamir dan laqabnya adalah; al-Taimīy, al-Bașrīy, al-Dār, wafat pada tahun 143 H. ${ }^{39}$

Gurunya adalah; Anas bin Mālik, 'Us̉mān al-Hindīy, Yażīd bin al-Syakhīr, Ṭāwūs, al-Hasan, Abī al-Naḍrah al-'Abdīy. ${ }^{40}$

Adapun murid-murid beliau adalah; Anaknya (al-Mu'tamir), Ibnu al-Mubārak, Ibnu 'Ilyah, Muḥammad bin 'Abdillāh al-Anșārīy, Yażīd bin Hārūn, Abū 'Āṣim. ${ }^{41}$

Di mata para kritikus, Sulaymān adalah seseorang yang sangat dipercaya sebagaimana ungkapan al-Rabī' bin Yạ̣ya, Ibnu Ma'īn dan para sahabatnya menggelarinya sebagai orang yang siqat, Ibnu Sa'ad juga mengomentarinya serupa dan menyatakan bahwa beliau memiliki banyak hadis, termasuk dalam kategori kelompok mujtahid yang shalat malam dengan wudhu dari shalat Isya. Dia beserta

${ }^{36}$ Hajjāj bin Yūsuf al-Mazzi, Tahzib al-Kamāl, Juz 28, h. 252
${ }^{37}$ Hajjāj bin Yūsuf al-Mazzi, Tahzib al-Kamāl, Juz 28, h. 254.
${ }^{38}$ Hajjāj bin Yūsuf al-Mazzi, Tahzib al-Kamāl, Juz 28, h. 254.
${ }^{39}$ 'Abd al-Gaffār Sulaymān al-Bundārīy, Mausū'ah Rijal al-Kutub al-Tis'ah, Juz II, (Beyrūt: Dār al-Kutub al'Ilmiyah, t.th.), h. 95; Hajjāj bin Yūsuf al-Mazzi, Tahzib al-Kamāl, Juz 1, h. 540; Ibnu Hajar al-'Asqalānīy, Tahzīb, Juz IV, h. 201.

40 Syamsuddīn Abīy 'Abdillāh Muhammad bin Aḥmad bin Uṡmān bin Qīmāż, Tazhīb Tahzib alKamāl Fìy Asmā' al-Rijā, Jilid IV, (T.tp. al-Fārūq al-Hadīṡah li al-Ṭib’ah wa al-Nasyr, 2003), h. 150. IV, h. 151.

${ }^{41}$ Syamsuddīn Abīy 'Abdillāh Muḥammad bin Aḥmad bin Us̉mān bin Qīmāż, Tazhīb Tahzib, Jilid 


\section{Subehan Khalik}

anaknya sering melakukan perjalanan keliling antar masjid pada malam hari. ${ }^{42}$ Sulaymān wafat di Basra pada tahun $143 \mathrm{H}$, bulan Zulqaiddah. ${ }^{43}$

\section{Abd' Al-Raḥmān bin Mulli bin 'Amru bin 'Adīy Ibnu Wahab bin Rabī'ah bin} Sa'ad bin Ḥuzaymah bin Ka'ab bin Rifā'ah Ibnu Mālik, dikenal dengan kunniyah Abū 'Uṡmān digelari sebagai al-Hindīy, al-Bașrīy, al-Kūfìy. ${ }^{44}$ Beliau memeluk Islam pada masa Nabi saw. ${ }^{45}$

Gurunya adalah sebagai berikut ; 'Umar bin Khațāāb, 'Ali bin Abīy Ṭālib, Abū Żar, Ibnu Mas'ūd, Ṭalhahah, Abū Mūsā, ‘Āisyah. ${ }^{46}$

Murid-muridnya sebagai berikut; Qatādah, Ayyūb, al-Jarīr al-Sa'̄̄e, Dāwud bin Abīy al-Hindīy, Āșim al-Ahwāl ${ }^{47}$

Dalam kesehariannya, Abū Uṡmān dikenal sebagai figure yang telaten melaksanakan shalat pada malam hari dan pada siangnya melakukan puasa, sebagaimana yang diutarakan oleh Sulaymān al-Taymīy. ${ }^{48}$ Menurut sebagian riwayat menyatakan bahwa Abū Uṡmān telah melaksanakan beberapakali ibadah haji dan telah melaksanakan ibadah umrah sebanyak 60 kali. ${ }^{49}$ Al-Mu'tamir bin Sulaymān figure ini telah melaksanakan shalat sampai ia sarapan pada pagi harinya. IV, h. 153.

${ }^{42}$ Syamsuddīn Abīy 'Abdillāh Muḥammad bin Aḥmad bin Uṡmān bin Qīmāż, Tazhīb Tahzib, Jilid

${ }^{43}$ Syamsuddīn Abīy 'Abdillāh Muhammad bin Aḥmad bin Uṡmān bin Qīmāż, Tazhīb Tahzib, Jilid IV, h. 154.

44 ‘Abd al-Gaffār Sulaymān al-Bundārīy, Mausū’ah Rijal, Juz II, h. 448. VI, h. 57.

${ }^{45}$ Syamsuddīn Abīy 'Abdillāh Muḥammad bin Aḥmad bin Uṡmān bin Qīmāż, Tazhīb Tahzib, jilid VI, h. 57.

${ }^{46}$ Syamsuddīn Abīy 'Abdillāh Muḥammad bin Aḥmad bin Us̉mān bin Qīmāż, Tazhīb Tahzib, jilid

${ }^{47}$ Syamsuddīn Abīy 'Abdillāh Muḥammad bin Aḥmad bin Uṡmān bin Qīmāż, Tazhīb Tahzib, jilid VI, h. 57.

${ }^{48}$ Syamsuddīn Abīy 'Abdillāh Muḥammad bin Aḥmad bin Uṡmān bin Qīmāż, Tazhīb Tahzib, jilid VI, h. 57. VI, h. 59.

${ }^{49}$ Syamsuddīn Abīy 'Abdillāh Muḥammad bin Aḥmad bin Us̉mān bin Qīmāż, Tazhīb Tahzib, jilid 
Bahkan dia memiliki rombongan sahabat terdiri para anak yatim yang senantiasa menunggu makanan dari Abū Uṡmān dan ketika Ia wafat maka para anak yatim tadi berkata; "telah pergi sahabatku" ${ }^{50}$ Ia Wafat pada tahun $95 \mathrm{H}$. sementara itu Ibnu Ma’̄̄n menyatakan bahwa Abū Uṡmān wafat pada tahun $100 \mathrm{H}$. Sebagian riwayat menyatakan bahwa Abū Uṡmān telah menyertai sahabat Nabi Salmān al-Fārisīy selama 12 tahun. ${ }^{51}$

6. 'Abd al-Raḥmān bin Abīy Bakr. Kunniyahnya adalah: Abū Muhammad, Abū 'Abdillāh. Gelararannya: al-Taymīy, al-Quraysyīy. ${ }^{52}$ Nama lengkap nya adalah 'Abdullāh Ibn Ab̄̄y Quhāfah. Ia adalah saudara kandung dari 'Āisyah ra. Dia menyaksikan lansung perang Badar bersama kaum musyrikin kemudian menyatakan keislamannya dan ikut berhijrah bersama Rasulullah saw. sebelum fath Makkah. ${ }^{53}$ Sufyan bin Uyainah memberitakan dengan sanad yang berasal dari Ali bin Ziad bin Jud'ān bahwa 'Abd al-Raḥmān ikut serta dalam perang Yamāmah bersama Khalid bin Walid. Dalam perang tersebut ia membunuh tujuh orang pemuka perang dari kelompok musuh dan salah satunya adalah Panglima perang Yamāmah bernama Ibnu Ṭufayl. ${ }^{54}$

'Abd al-Raḥmān bin Abīy Bakr menerima riwayat lansung dari Rasulullah saw. dari Bapaknya Abū Bakr al-Șiddīq. ${ }^{55}$

Diantara murid-murid beliau adalah sebagai berikut: Sa’̄id bin Musayyab, Syuraih bin al-Ḥāris̀ al-Qāḍīy dan anaknya 'Abdullāh bin 'Abd al-Rahmān bin Abī Bakr alȘiddīq, Abdullāh bin 'Ubaidillāh bin Abī Mulaikah, 'Abdullāh bin Ka'ab, 'Abd alRahmān bin Abīy Laylīy, 'Amr bin Uways al-Ṣaqafīy, serta anak perempuannya VI, h. 59

${ }^{50}$ Syamsuddīn Abīy 'Abdillāh Muḥammad bin Aḥmad bin Uṡmān bin Qīmāż, Tazhīb Tahzib, jilid VI, h. 59.

${ }^{51}$ Syamsuddīn Abīy 'Abdillāh Muḥammad bin Aḥmad bin Uṡmān bin Qīmāż, Tazhīb Tahzib, jilid

\footnotetext{
52 'Abd al-Gaffār Sulaymān al-Bundārīy, Mausū'ah Rijal al-Kutub al-Tis'ah, Juz II, h. 397

${ }^{53}$ Ḥajjāj bin Yūsuf al-Mazzi, Tahzib al-Kamāl, Juz 6, h. 555.

${ }^{54}$ Ḥajjāj bin Yūsuf al-Mazzi, Tahzib al-Kamāl, Juz 6, h. 556

${ }^{55}$ Ḥajjāj bin Yūsuf al-Mazzi, Tahzib al-Kamāl, Juz 6, h. 556
} 


\section{Subehan Khalik}

Hafṣah binti 'Abd al-Raḥmān bin Abīy Bakar al-Șiddīq. ${ }^{56}$ Para sahabat memberi penilaian dalam hal kepribadian kepada 'Abd al-Raḥmān bin Abīy Bakar al-Ṣiddīq sebagai figur yang saleh sebagaimana ungkapan dari Zubayr bin Bakkār. ${ }^{57}$ Ma'mar berkata dengan sanad yang disandarkan kepada al-Zuhri, dari Ibnu al-Musayyab dalam hadisnya yang menyebut bahwa 'Abd al-Raḥmān bin Abīy Bakar al-Ṣiddīq; “Tidak pernah bersentuhan dengan kebohongan sesaat pun". ${ }^{58}$ Abū Zur'ah alDamsyiqīy meriwayatkan bahwa 'Abd al-Raḥmān bin Abīy Bakar al-Ṣiddīq wafat ketika Mu'awiyah mengakhiri kunjungannya ke Madinah al-Munawwarah dalam rangka menerima bai'at dari 'Abdullāh bin 'Umar, 'Abdullāh bin Zubayr dan 'Abd al-Raḥmān bin Abīy Bakar al-Șiddīq. ${ }^{59}$ Peristiwa ini beriringan dengan wafatnya 'Āisyah ra. Pada tahun 59 H. Namun riwayat menjelaskan bahwa 'Abd al-Raḥmān bin Abīy Bakar al-Ṣiddīq wafat pada tahun $55 \mathrm{H}^{60}$

Pada skema kedua terlihat bahwa jalur Muslim yang terpilih menjadikan 'Abd alRaḥmān bin Abī Bakr selaku periwayat I sanad ke 6, Abū Us̉mān selaku periwayat II sanad ke 5, Abī (akan diungkap identitas pada saat kritik sanad) selaku periwayat ke III dan sanad ke 4, al-Mu'tamir bin Sulaimān selaku periwayat ke IV dan sanad ke 3, Abū al-Nu'mān selaku periwayat ke V dan sanad ke 2 serta Imam Bukhārīy selaku periwayat ke VI dan sanad Pertama. Sebagaimana terlihat dalam diagram, masing-masing periwayat dalam ketersambungan sanadnya menggunakan șigat al-tahammul masingmasing; haddasianā, 'an dan qāla. (Lihat kembali skema kedua pada lembar halaman selanjutnya).

Karena terjadi kesamaan para periwayat dari jalur Imam Muslim dan Imam Bukhārīy kecuali pada sanad kedua dan pertama, maka pada pembahasan rijāl al-hadīì hanya akan membahas kedua periwayat ini, begitupula pada diagram ketiga nantinya.

\footnotetext{
${ }^{56}$ Ḥajjāj bin Yūsuf al-Mazzi, Tahzib al-Kamāl, Juz 6, h. 557

${ }^{57}$ Hajjāj bin Yūsuf al-Mazzi, Tahzib al-Kamāl, Juz 6, h. 557

${ }^{58}$ Ḥajjāj bin Yūsuf al-Mazzi, Tahzib al-Kamāl, Juz 6, h. 557

${ }^{59}$ Ḥajjāj bin Yūsuf al-Mazzi, Tahzib al-Kamāl, Juz 6, h. 557

${ }^{60}$ Ḥajjāj bin Yūsuf al-Mazzi, Tahzib al-Kamāl, Juz 6, h. 557
} 


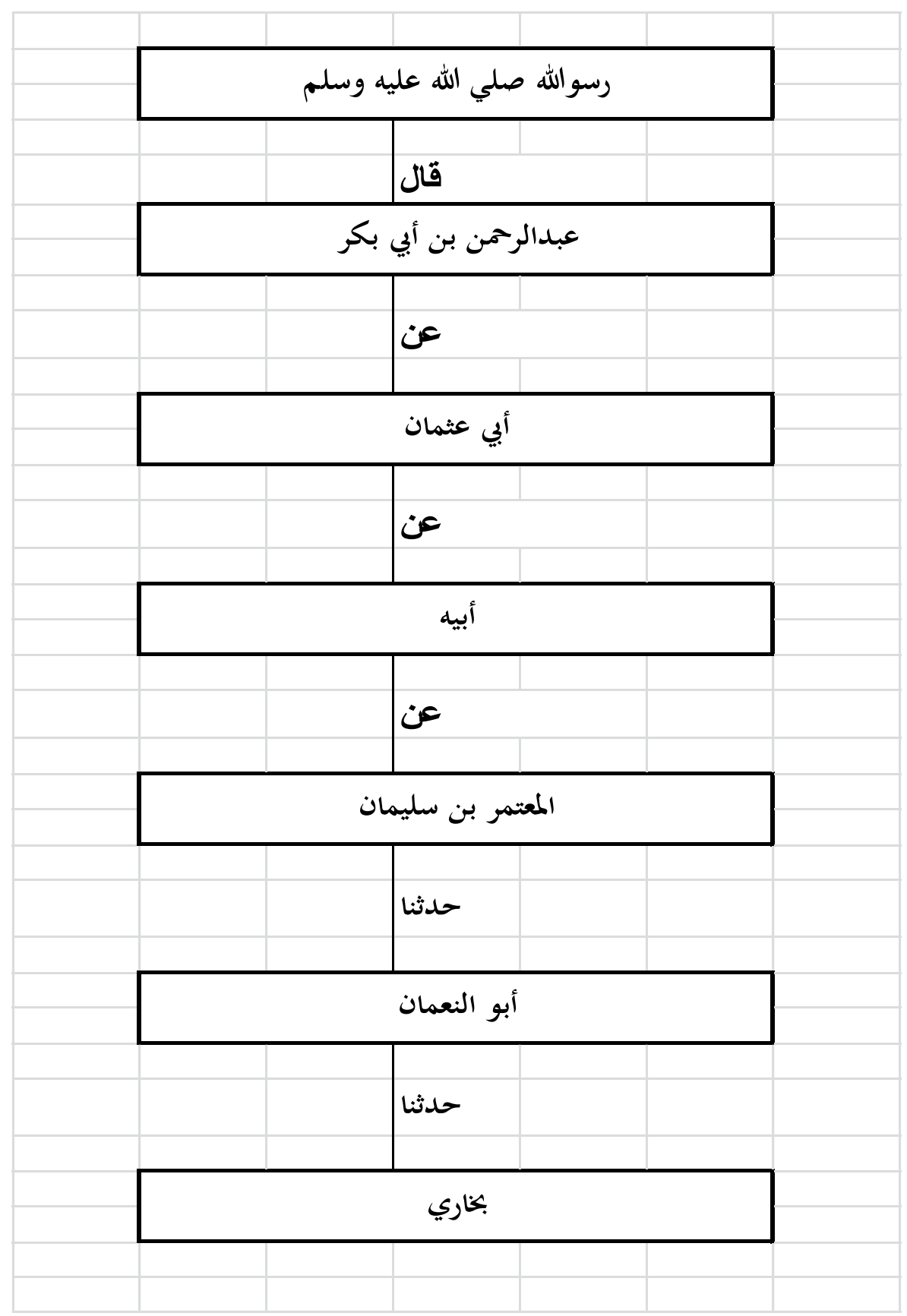

Berikut ini diuraikan biografi singkat serta penilaian kritikus hadis terhadap masing-masing tokoh yang terlihat dalam diagram I di depan yaitu;

1. Imam Bukhāriy, Bernama Muhammad bin Ismā̄êl bin Ibrāhīm bin al-Mugīrah Ibn Bardiżabah. ${ }^{61}$

${ }^{61}$ Ḥajjāj bin Yūsuf al-Mazzi, Tahzib al-Kamāl, Juz 24, h. 430 


\section{Subehan Khalik}

Guru-gurunya; Ibrāhīm bin Ḥamzah al-Żubayr, Ibrāhīm bin al-Munzir al-Ḥiżżāmīy, Aḥmad bin Ḥanbal, Aḥmad bin Șālih al-Miṣrīy, Aḥmad bin Abīy Ṭayyib alMarważīy, Aḥmad bin Muāammad al-Ażraqīy, Ayyūb bin Sulaimān bin Bilāl, Yaḥya bin Ma'īn, Hisyam bin Ismā'îl al'Aț̣ār al-Damsyiqīy. ${ }^{62}$

Para murid beliau diantaranya adalah: Al-Tirmizīy, Ibrāhīm bin Isḥāq al-Ḥarbīy, Ibrāhīm bin Ma'qil al-Nasafīy, Abū Bakr Aḥmad bin 'Amru bin Abī Āṣim, Abū al'Abbās Aḥmad bin Muḥammad bin al-Azhar al-Azhar al-Naysabūrīy. ${ }^{63}$

Berikut diuraikan pula kritik para ahli hadis terhadap eksistensi Imām Bukhārīy dalam dunia periwayatan; al-Ḥasan bin al-Ḥusayn berkata; "Saya melihat Imām alBukhārīy sebagai figur yang memiliki fisik yang tidak pendek dan tidak pula tinggi. Dilahirkan pada hari Jum'at sesudah shalat Jum'at 13 Syawal 194 H. dan wafat pada malam Sabtu pada saat masuk waktu Isya malam lebaran Idul Fitri dan kemudian dikebumikan pada esok harinya pada tanggal 1 Syawal $256 \mathrm{H}^{64}$

2. Muḥammad bin 'Abd al-A'lā. Ia adalah Muḥammad bin 'Abd al-A'lā al-Ṣan'ānīy al-Qaysīy, dikenal pula dengan nama Abū 'Abdullah al-Bașrīy. ${ }^{65}$

Gurunya adalah; Ismā'il bin 'Ulaiyah, Ummiyah bin Khālid, Khālid Ibn al-Ḥaris̀, Sufyān bin Uyainah, Salamah bin Raja', 'Abd al-Rahmān bin Mahdi, 'Abd alRazzāq bin Hammām, Imrān bin Uyainah. ${ }^{66}$

Muridnya-muridnya; Abū Dāwud, Ibrāḥ̄im bin 'Abdullāh al-'Askarīy al-Zabīybīy, Ibrāḥīm ybin Yūsuf bin Nukhrah bin al-Ḥasan al-Ṣan’ānīy, Abū Bakar Aḥmad bin 'Amru bin Abīy 'Āṣim, Baqīy bin Makhlad al-Andalūsīy, Ja'far bin Muhammad alFiryābīy ${ }^{67}$ Para kritikus memberi penilaian kepada Muḥammad bin 'Abd al-A'lā

${ }^{62}$ Hajjāj bin Yūsuf al-Mazzi, Tahzib al-Kamāl, Juz 24, h. 430-434.

${ }^{63}$ Hajjāj bin Yūsuf al-Mazzi, Tahzib al-Kamāl, Juz 24, h. 432

${ }^{64}$ Hajjāj bin Yūsuf al-Mazzi, Tahzib al-Kamāl, Juz 24, h. 444

${ }^{65}$ Hajjāj bin Yūsuf al-Mazzi, Tahzib al-Kamāl fi Asma' al-Rijal, Jilid V, (Beirūt: Mu'assah alRisalah, 1997), h. 581.

${ }^{66}$ Hajjāj bin Yūsuf al-Mazzi, Tahzib al-Kamāl, h. 582.

${ }^{67}$ Hajjāj bin Yūsuf al-Mazzi, Tahzib al-Kamāl, h. 582 
sebagai berikut; Abū Zur'ah dan Abū Ḥātim menilai; siqqah, Ibnu Hịbān juga menyebut figur ini dalam kitab "al-Śiqāt", Sementara itu Imam Bukhārīy menjelaskan bahwa figure ini wafat pada tahun $245 \mathrm{H}$. di Basrah. ${ }^{68}$

3. Mu'tamir bin Sulaimān bin Turkhān (wafat $187 \mathrm{H}$ ). Kunniyahnya adalah Abū Muḥammad al-Bașrīy. ${ }^{69}$

Gurunya adalah; Ibrāhim bin Yazīd al-Khużīy, al-Akhụār bin Yazīd, Isḥāq bin Suwaidi al-‘Adawīy, Ismā’̄̄l bin Ḥammād, Ismā’̄̄l bin Khālid, Ayyāsy bin Dagfal, Burda bin Sinān al-Syāmmīy. ${ }^{70}$ Muridnya adalah: Aḥmad bin Hanbal, Aḥmad bin 'Abdah al-Ḍabbīy, Abū al-Asy’ab Aḥmad bin al-Miqdām al-'Ijlīy, Isḥaq bin Ibrāhim bin Hayba bin al-Syaḥīd, ${ }^{71}$ Di mata kritikus periwayat hadis, al-Mu'tamir adalah seorang yang siqat sebagaimana ungkapan Isḥaq bin Manșūr, demikian juga pernyataan Yaḥyā bin Ma'īn serta Abū Hātim; siquat, șadūq. ${ }^{72}$ Al-Mu'tamir lahir pada tahun $106 \mathrm{H}$ dan wafat pada tahun $187 \mathrm{H}$ di Basrah pada masa pemerintahan Khalifah Harun al-Rasyid. ${ }^{73}$

4. Sulaimān bin Ṭurkhān, Kunniyahnya adalah Abū al-Mu'tamir dan laqabnya adalah; al-Taimīy, al-Bașrīy, al-Dār, wafat pada tahun $143 \mathrm{H}^{74}$

Gurunya adalah; Anas bin Mālik, 'Uṡmān al-Hindīy, Yażīd bin al-Syakhīr, Ṭāwūs, al-Hasan, Abī al-Naḍrah al-'Abdīy. ${ }^{75}$

${ }^{68}$ Hajjāj bin Yūsuf al-Mazzi, Tahzib al-Kamāl, h. 583

${ }^{69}$ Hajjāj bin Yūsuf al-Mazzi, Tahzib al-Kamāl, Juz 28, h. 251

${ }^{70}$ Hajjāj bin Yūsuf al-Mazzi, Tahzib al-Kamāl, Juz 28, h. 251

${ }^{71}$ Hajjāj bin Yūsuf al-Mazzi, Tahzib al-Kamāl, Juz 28, h. 252

${ }^{72}$ Ḥajjāj bin Yūsuf al-Mazzi, Tahzib al-Kamāl, Juz 28, h. 254.

${ }^{73}$ Hajajāj bin Yūsuf al-Mazzi, Tahzib al-Kamāl, Juz 28, h. 254.

74 'Abd al-Gaffār Sulaymān al-Bundārīy, Mausū'ah Rijal al-Kutub al-Tis'ah, Juz II, (Beyrūt: Dār al-Kutub al'Ilmiyah, t.th.), h. 95; Hajjāj bin Yūsuf al-Mazzi, Tahzib al-Kamāl, Juz 1, h. 540; Ibnu Hajar al-'Asqalānīy, Tahzīb, Juz IV, h. 201.

${ }^{75}$ Syamsuddīn Abīy 'Abdillāh Muḥammad bin Aḥmad bin Us̉mān bin Qīmāż, Tazhīb Tahzib alKamāl Fìy Asmā’ al-Rijā, Jilid IV, (T.tp. al-Fārūq al-Ḥadīsah li al-Ṭib’ah wa al-Nasyr, 2003), h. 150. 
Adapun murid-murid beliau adalah; Anaknya (al-Mu'tamir), Ibnu al-Mubārak, Ibnu 'Ilyah, Muhammad bin 'Abdillāh al-Anșārīy, Yażīd bin Hārūn, Abū ‘Āṣim. ${ }^{76}$ Di mata para kritikus, Sulaymān adalah seseorang yang sangat dipercaya sebagaimana ungkapan al-Rabî̀ bin Yahya, Ibnu Ma'în dan para sahabatnya menggelarinya sebagai orang yang siqat, Ibnu Sa'ad juga mengomentarinya serupa dan menyatakan bahwa beliau memiliki banyak hadis, termasuk dalam kategori kelompok mujtahid yang shalat malam dengan wudhu dari shalat Isya. Dia beserta anaknya sering melakukan perjalanan keliling antar masjid pada malam hari. ${ }^{77}$ Sulaymān wafat di Basra pada tahun $143 \mathrm{H}$, bulan Zulqaiddah. ${ }^{78}$

7. Abd' Al-Raḥmān bin Mulli bin 'Amru bin 'Adīy Ibnu Wahab bin Rab̄̄'ah bin Sa'ad bin Ḥuzaymah bin Ka'ab bin Rifā'ah Ibnu Mālik, dikenal dengan kunniyah Abū 'Uṡmān digelari sebagai al-Hindīy, al-Bașrīy, al-Kūfīy. ${ }^{79}$ Beliau memeluk Islam pada masa Nabi saw. ${ }^{80}$

Gurunya aadalah sebagai berikut ; 'Umar bin Khatțāb, 'Ali bin Abīy Ṭālib, Abū Żar, Ibnu Mas'ūd, Ṭalhahah, Abū Mūsā, 'Āisyah. ${ }^{81}$

Murid-muridnya sebagai berikut; Qatādah, Ayyūb, al-Jarīr al-Sa'̄̄e, Dāwud bin Abīy al-Hindīy, Āṣim al-Ahwāl ${ }^{82}$

$$
\text { IV, h. } 151 .
$$

${ }^{76}$ Syamsuddīn Abīy 'Abdillāh Muhammad bin Aḥmad bin Uṡmān bin Qīmāż, Tazhīb Tahzib, Jilid

${ }^{77}$ Syamsuddīn Abīy ‘Abdillāh Muḥammad bin Aḥmad bin Uṡmān bin Qīmāż, Tazhīb Tahzib, Jilid IV, h. 153. IV, h. 154.

${ }^{78}$ Syamsuddīn Abīy 'Abdillāh Muḥammad bin Aḥmad bin Us̉mān bin Qīmāż, Tazhīb Tahzib, Jilid

79 ‘Abd al-Gaffār Sulaymān al-Bundārīy, Mausū’ah Rijal, Juz II, h. 448.

${ }^{80}$ Syamsuddīn Ab̄̄y 'Abdillāh Muḥammad bin Aḥmad bin Uṡmān bin Qīmāż, Tazhīb Tahzib, jilid VI, h. 57.

${ }^{81}$ Syamsuddīn Abīy 'Abdillāh Muḥammad bin Aḥmad bin Us̉mān bin Qīmāż, Tazh̄̄b Tahzib, jilid VI, h. 57. VI, h. 57.

${ }^{82}$ Syamsuddīn Abīy 'Abdillāh Muḥammad bin Aḥmad bin Us̉mān bin Qīmāż, Tazhīb Tahzib, jilid 
Dalam kesehariannya, Abū Uṡmān dikenal sebagai figure yang telaten melaksanakan shalat pada malam hari dan pada siangnya melakukan puasa, sebagaimana yang diutarakan oleh Sulaymān al-Taymīy. ${ }^{83}$ Menurut sebagian riwayat menyatakan bahwa Abū Uṡmān telah melaksanakan beberapakali ibadah haji dan telah melaksanakan ibadah umrah sebanyak 60 kali. ${ }^{84}$ Al-Mu'tamir bin Sulaymān figure ini telah melaksanakan shalat sampai ia sarapan pada pagi harinya. Bahkan dia memiliki rombongan sahabat terdiri para anak yatim yang senantiasa menunggu makanan dari Abū Uśmān dan ketika Ia wafat maka para anak yatim tadi berkata; "telah pergi sahabatku" 85 Ia Wafat pada tahun $95 \mathrm{H}$. sementara itu Ibnu Ma'īn menyatakan bahwa Abū Us̉mān wafat pada tahun $100 \mathrm{H}$. Sebagian riwayat menyatakan bahwa Abū Uṡmān telah menyertai sahabat Nabi Salmān al-Fārisīy selama 12 tahun. ${ }^{86}$

8. 'Abd al-Raḥmān bin Abīy Bakr. Kunniyahnya adalah: Abū Muḥammad, Abū 'Abdillāh. Gelararannya: al-Taymīy, al-Quraysyīy. ${ }^{87}$ Nama lengkap nya adalah 'Abdullāh Ibn Abīy Quhāfah. Ia adalah saudara kandung dari 'Āisyah ra. Dia menyaksikan lansung perang Badar bersama kaum musyrikin kemudian menyatakan keislamannya dan ikut berhijrah bersama Rasulullah saw. sebelum fath Makkah. ${ }^{88}$ Sufyan bin Uyainah memberitakan dengan sanad yang berasal dari Ali bin Ziad bin Jud'ān bahwa 'Abd al-Raḥmān ikut serta dalam perang Yamāmah bersama Khalid bin Walid. Dalam perang tersebut ia membunuh tujuh orang VI, h. 57.

${ }^{83}$ Syamsuddīn Abīy 'Abdillāh Muḥammad bin Aḥmad bin Uṡmān bin Qīmāż, Tazhīb Tahzib, jilid

${ }^{84}$ Syamsuddīn Abīy 'Abdillāh Muḥammad bin Aḥmad bin Uṡmān bin Qīmāż, Tazhīb Tahzib, jilid VI, h. 59. VI, h. 59

${ }^{85}$ Syamsuddīn Abīy 'Abdillāh Muḥammad bin Aḥmad bin Us̉mān bin Qīmāż, Tazhīb Tahzib, jilid

${ }^{86}$ Syamsuddīn Abīy 'Abdillāh Muhammad bin Aḥmad bin Uṡmān bin Qīmāż, Tazhīb Tahzib, jilid VI, h. 59.

\footnotetext{
87 ‘Abd al-Gaffār Sulaymān al-Bundārīy, Mausū'ah Rijal al-Kutub al-Tis'ah, Juz II, h. 397

${ }^{88}$ Hajjāj bin Yūsuf al-Mazzi, Tahzib al-Kamāl, Juz 6, h. 555.
} 


\section{Subehan Khalik}

pemuka perang dari kelompok musuh dan salah satunya adalah Panglima perang Yamāmah bernama Ibnu Ṭufayl. ${ }^{89}$

'Abd al-Raḥmān bin Abīy Bakr menerima riwayat lansung dari Rasulullah saw. dari Bapaknya Abū Bakr al-Ṣiddīq. ${ }^{90}$

Diantara murid-murid beliau adalah sebagai berikut: Sa’̄id bin Musayyab, Syuraih bin al-Ḥāris̉ al-Qāọ̄īy dan anaknya 'Abdullāh bin 'Abd al-Rahmān bin Ab̄̄ Bakr alȘiddīq, Abdullāh bin 'Ubaidillāh bin Abī Mulaikah, 'Abdullāh bin Ka'ab, 'Abd alRahmān bin Abīy Laylīy, 'Amr bin Uways al-Ṣaqafìy, serta anak perempuannya Hafṣah binti 'Abd al-Raḥmān bin Abīy Bakar al-Șiddīq. ${ }^{91}$ Para sahabat memberi penilaian dalam hal kepribadian kepada 'Abd al-Raḥmān bin Abīy Bakar al-Ṣiddīq sebagai figur yang saleh sebagaimana ungkapan dari Zubayr bin Bakkār. ${ }^{92}$ Ma'mar berkata dengan sanad yang disandarkan kepada al-Zuhri, dari Ibnu al-Musayyab dalam hadisnya yang menyebut bahwa 'Abd al-Raḥmān bin Abīy Bakar al-Ṣiddīq; "Tidak pernah bersentuhan dengan kebohongan sesaat pun". 93 Abū Zur'ah alDamsyiqīy meriwayatkan bahwa 'Abd al-Raḥmān bin Abīy Bakar al-Ṣiddīq wafat ketika Mu'awiyah mengakhiri kunjungannya ke Madinah al-Munawwarah dalam rangka menerima bai'at dari 'Abdullāh bin 'Umar, 'Abdullāh bin Zubayr dan 'Abd al-Raḥmān bin Abīy Bakar al-Ṣiddīq. ${ }^{94}$ Peristiwa ini beriringan dengan wafatnya 'Āisyah ra. Pada tahun 59 H. Namun riwayat menjelaskan bahwa 'Abd al-Raḥmān bin Abīy Bakar al-Ṣiddīq wafat pada tahun 55 H. ${ }^{95}$

\footnotetext{
${ }^{89}$ Hajjāj bin Yūsuf al-Mazzi, Tahzib al-Kamāl, Juz 6, h. 556

${ }^{90}$ Hajjāj bin Yūsuf al-Mazzi, Tahzib al-Kamāl, Juz 6, h. 556

${ }^{91}$ Ḥajjāj bin Yūsuf al-Mazzi, Tahzib al-Kamāl, Juz 6, h. 557

${ }^{92}$ Hajjāj bin Yūsuf al-Mazzi, Tahzib al-Kamāl, Juz 6, h. 557

${ }^{93}$ Ḥajjāj bin Yūsuf al-Mazzi, Tahzib al-Kamāl, Juz 6, h. 557

${ }^{94}$ Ḥajjāj bin Yūsuf al-Mazzi, Tahzib al-Kamāl, Juz 6, h. 557

${ }^{95}$ Ḥajjāj bin Yūsuf al-Mazzi, Tahzib al-Kamāl, Juz 6, h. 557
} 


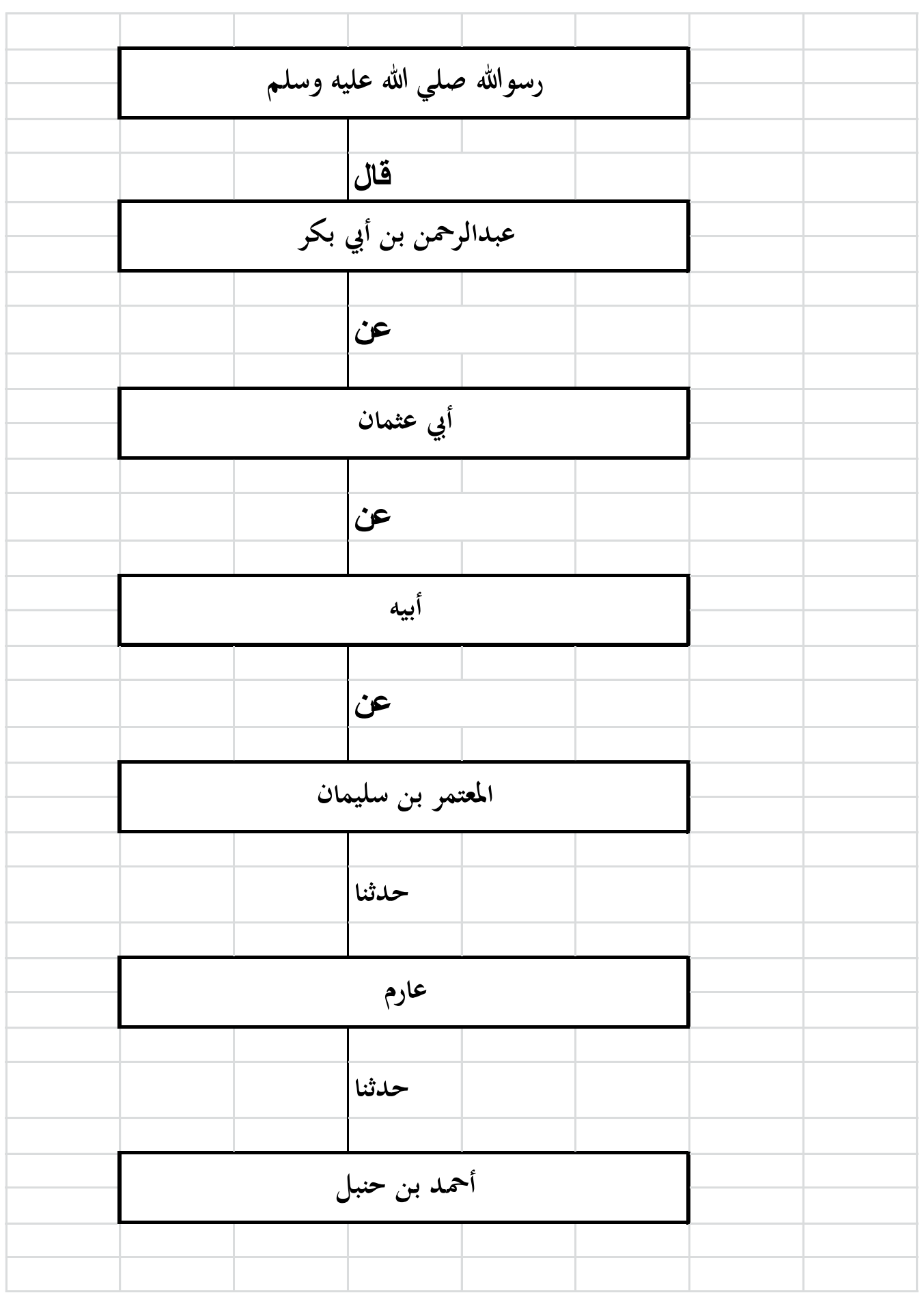

Pada skema terdepan terlihat bahwa jalur Muslim yang terpilih menjadikan 'Abd al-Raḥmān bin Abī Bakr selaku periwayat I sanad ke 6, Abū Us̉mān selaku periwayat II sanad ke 5, Abī (akan diungkap identitas pada saat kritik sanad) selaku periwayat ke III dan sanad ke 4, al-Mu'tamir bin Sulaimān selaku periwayat ke IV dan sanad ke 3, 
'Ārim (Muhammad bin al-Faḍl al-Sadūsīy Abū al-Nu’mān al-Bașrīy) selaku periwayat ke V dan sanad ke 2 serta Imam Aḥmad bin Ḥanbal selaku periwayat ke VI dan sanad Pertama. Sebagaimana terlihat dalam diagram, masing-masing periwayat dalam ketersambungan sanadnya menggunakan șigat al-taḥammul masing-masing; ḩaddasianā, 'an dan qāla.

1. Ahmad ibn Hanbal. ${ }^{96}$ Dia adalah Ahmad ibn Muhammad ibn Hanbal ibn Hilal ibn Asad al-Syaybaniy Abu `Abd Allah al-Marwaziy al-Bagdadiy (164-241 H.).

Guru Aḥmad bin Hanbal cukup banyak, antara lain 'Affan bin Muslim bin 'Abd Alla al S ${ }^{\circ}$ affar, Ibrahim ibn Khalid al-S ${ }^{\circ}$ an 'aniy, Sufyan ibn 'Uyainat, Qutaybat bin Sa'id, 'Abd al-Rahman ibn Mahdiy, dan 'Abd Allah ibn Numayr al-H amdaniy. Murid Ahmad juga banyak, antara lain al-Bukhariy (w. 256 H.), Muslim (w. 261 H.), dua orang puteranya, `Abd Allah dan Salih. ${ }^{97}$

a. Ahmad adalah periwayat hadis yang terpuji kualitas pribadi (sifat adil) dan kapasitas intelektualnya (sifat dabit) nya. Terbukti dari pernyataan para kritikus hadis tentang dirinya:

b. Al-Qat ऊँỡān (w. 198 H.): Tidak ada orang yang datang kepada saya yang kebaikannya melebihi Ahmad. Dia hiasan umat khususnya hadis Nabi.

c. Ibn Ma in (158-233 H.): Saya tidak melihat orang yang baik (pengetahuan nya di bidang hadis) melebihi Ahmad.

d. Al-Syafi'iy (w. 204 H.): Saya keluar dari Bagdad dan saya tidak ada menemukan orang yang lebih mulia, alim, fakih, dan lebih warak daripada Ahmad bin Hanbal.

\footnotetext{
${ }^{96}$ Hajjāj bin Yūsuf al-Mazzi, Tahzib al-Kamāl, juz I, h. 226 dan 249; Abu Muhammad `Abd alRaḥmān ibn Abīy Hātim al-Ra ziy, Ab̄̄ Muḥammad 'Abd al-Rahmān bin Ab̄ìy Hātim Muḥammad bin Idrīs bin Munzir al-Tamīymīy al-Hazalīy al-Rāzīy, Kitāb al-Jarh al-Ta'dīl, juz II h. 68 dan 70; Jalāl al-

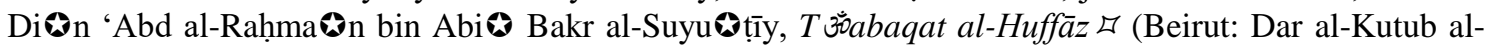
'Ilmiyyah, 1983 M.), h. 189 dan 191; Abu al-Hasan `Ali ibn 'Umar ibn Aḥmad al-Dāraqutniy, Zikr Asmā'

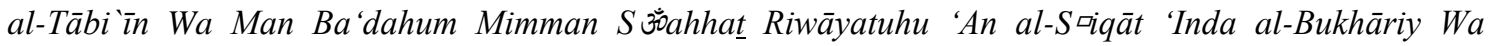
Muslim, juz I (Beirut: Mu'assasat al-Kutub al-Saqafiyyah, 1986 M.), h. 66; Abū Bakr Aḥmad ibn 'Ali alKhat ऊँ̄̄b al-Bagdādīy, Tārikh Bagdād aw Madīnat al-Salām, juz IV (Al-Madinat al-Munawwarah: alMaktabat al-Salafiyyah, t.th.), h. 421-22; Ibrahim Dasuqiy al-Syahawiy, Must ॐّalah al-Hadīs $\square$ (Kairo: Syirkat al-Tふّaba'at al-Fanniyyat al-Muttahidah, t.th.), h. 234.

${ }^{97}$ Hajjāj bin Yūsuf al-Mazzi, Tahzib al-Kamāl, Juz 4, h. 227-230; al-`Asqalāniy, Tahzîb al-Tahzîlb., jilid I, (Beirut: Dār al-Fikr, 1984 M), h. 62-3; al-Zahabiy, “Siyar”, juz XI, h. 180-184.
} 
e. Ibn al-Madiniy (161-234 H.): Tidak ada seorang pun di antara sahabatku yang lebih hafiz dari Ahmad. Sungguh Allah telah memperkuat agama (Islam) ini dengan Abu Bakr al-Siddiq pada peristiwa al-riddat dan dengan Ahmad bin Hanbal pada peristiwa al-mihnat.

f. Al-Nasa'iy $\left(215-303\right.$ H.): Ahmad itu siqat ma'mūn..$^{98}$

g. Tidak seorang pun yang mencela Ahmad. Sebaliknya, pujian yang diberikan kepadanya adalah yang berperingkat tinggi dan tertinggi.

Dengan menggunakan lambang $s$ ఐana $\$$ metode al-Sama', maka tidak diragukan lagi kalau ia memang menerima riwayat dari salah seorang gurunya yang bernama lain 'Affan bin Muslim bin 'Abd Alla hal-S 30 affar. Keyakinan ini juga dapat dibuktikan secara terbalik setelah menelusuri riwayat hidup gurunya. Ini kembali membuktikan bahwa telah terjadi ketersambungan sanad antara Ah ${ }^{\circ}$ mad dengan 'Affa bin Muslim bin 'Abd Alla hal-S 30 affa

2. 'Ārim adalah gelaran terhadap Muhammah bin al-Fạ̣l al-Sadūsīy, Abū alNu'mān. ${ }^{99}$

Gurunya adalah: Abīy Żaid bin Sābit bin Yażīd al-Aḥwāl, Jarīr bin Hạżim, Ḥammād bin Żayd, Hammād bin Salamah, Dāwūd bin Ab̄̄y al-Furāt, Sa’̄̄d bin Żayd, 'Abdullāh bin Mubārak, 'Abd al-Wāḥid bin Żiyād, ‘Abd al-Wāris̀ Ibnu Sa’̄̄d, Mu'tamar bin Sulaimān. ${ }^{100}$

${ }^{98}$ Al-Zahabi, Kitab Tazkirat al-Huffaz, juz II (Beirut: Dar Ihya' al-Turas' al-`Arabiy, 1375 H./1955 M.), h. 431-432; Muhammad 'Abdullāh al-Jardaniy, Fath 3ٌ al-'Allām bi Syarh Mursyid alAna fi Fiqh 'ala Maz hab al-Sada al-Sya fi iyah, Juz IV (al-Madinat al-Munawwarah: Dār alSalam li al-Tふँنiba'at wa al-Nasyr, 1990 M.), h. 514; Abu Muhammad Abdul Mahdi bin Abdul Qadir bin Abdul Hadi, Tॐuruq Takhri Hadi Rasulullah saw., diterjemahkan oleh H.S.Agil Husin Munawwar dan H.Ahmad Rifqi Muchtar, Metode Takhrij Hadits (Semarang: Cet. I; Dina Utama, 1994), h. 111-112.

${ }^{99}$ Ḥajjāj bin Yūsuf al-Mazzi, Tahzib al-Kamāl, Juz 26, h. 288.

${ }^{100}$ Hajjāj bin Yūsuf al-Mazzi, Tahzib al-Kamāl, Juz 26, h. 288 


\section{Subehan Khalik}

Diantara murid yang menerima riwayat darinya adalah: al-Bukhārīy, Ibrāhīm bin Harb al-'Askarīy, Abū Muslim Ibrāhīm bin Ḥarb al-Kajjiyyu, Aḥmad bin Sa’̄̄d alDārimīy. ${ }^{101}$

Dalam pandangan kritikus hadis, figur 'Ārim adalah sebagai berikut: Menurut Muhammad bin Muslim bin Wārat; Dia ('Ārim) adalah seorang yang șadūq, $m a ' m \bar{u} n .{ }^{102}$ Menurut Imam al-Bukhārīy, Dia ('Ārim) mengalami perubahan dalam hafalan pada akhir hayatnya. ${ }^{103}$ 'Ārim wafat pada tahun $223 \mathrm{H} .{ }^{104}$

3. Mu'tamir bin Sulaimān bin Turkhān (wafat $187 \mathrm{H}$ ). Kunniyahnya adalah Abū Muḥammad al-Bașrīy. ${ }^{105}$ Gurunya adalah; Ibrāhim bin Yazīd al-Khużīy, al-Akhḍār bin Yazīd, Isḥāq bin Suwaidi al-‘Adawīy, Ismā’̄il bin Ḥammād, Ismā’̂̄l bin Khālid, Ayyāsy bin Dagfal, Burda bin Sinān al-Syāmmīy. ${ }^{106}$

Muridnya adalah: Aḥmad bin Hanbal, Aḥmad bin 'Abdah al-Ḍabbīy, Abū alAsy’ab Aḥmad bin al-Miqdām al-'Ijlīy, Isḥaq bin Ibrāhim bin Ḥayba bin al-Syahịid, 107 Di mata kritikus periwayat hadis, al-Mu'tamir adalah seorang yang siqat sebagaimana ungkapan Isḥaq bin Manșūr, demikian juga pernyataan Yahyā bin Ma'īn serta Abū Hātim; siqat, șadūq. ${ }^{108}$ Al-Mu'tamir lahir pada tahun $106 \mathrm{H}$ dan wafat pada tahun $187 \mathrm{H}$ di Basrah pada masa pemerintahan Khalifah Harun alRasyid. ${ }^{109}$

\footnotetext{
${ }^{101}$ Hajjāj bin Yūsuf al-Mazzi, Tahzib al-Kamāl, Juz 26, h. 288

${ }^{102}$ Hajjāj bin Yūsuf al-Mazzi, Tahzib al-Kamāl, Juz 26, h. 288

${ }^{103}$ Hajjāj bin Yūsuf al-Mazzi, Tahzib al-Kamāl, Juz 26, h. 288

${ }^{104}$ Hajjāj bin Yūsuf al-Mazzi, Tahzib al-Kamāl, Juz 26, h. 288

${ }^{105}$ Hajjāj bin Yūsuf al-Mazzi, Tahzib al-Kamāl, Juz 28, h. 251

${ }^{106}$ Hajjāj bin Yūsuf al-Mazzi, Tahzib al-Kamāl, Juz 28, h. 251

${ }^{107}$ Hajjāj bin Yūsuf al-Mazzi, Tahzib al-Kamāl, Juz 28, h. 252

${ }^{108}$ Hajjāj bin Yūsuf al-Mazzi, Tahzib al-Kamāl, Juz 28, h. 254.

${ }^{109}$ Hajjāj bin Yūsuf al-Mazzi, Tahzib al-Kamāl, Juz 28, h. 254.
} 
4. Sulaimān bin Turkhān, Kunniyahnya adalah Abū al-Mu'tamir dan laqabnya adalah; al-Taimīy, al-Bașrīy, al-Dār, wafat pada tahun 143 H. ${ }^{110}$ Gurunya adalah; Anas bin Mālik, 'Uṡmān al-Hindīy, Yażīd bin al-Syakhīr, Ṭāwūs, al-Hasan, Abī alNaḍrah al-'Abdīy. ${ }^{111}$ Adapun murid-murid beliau adalah; Anaknya (al-Mu’tamir), Ibnu al-Mubārak, Ibnu 'Ilyah, Muḥammad bin 'Abdillāh al-Anșārīy, Yażīd bin Hārūn, Abū 'Āṣim. ${ }^{112}$

Di mata para kritikus, Sulaymān adalah seseorang yang sangat dipercaya sebagaimana ungkapan al-Rabì' bin Yahya, Ibnu Ma'īn dan para sahabatnya menggelarinya sebagai orang yang siqat, Ibnu Sa'ad juga mengomentarinya serupa dan menyatakan bahwa beliau memiliki banyak hadis, termasuk dalam kategori kelompok mujtahid yang shalat malam dengan wudhu dari shalat Isya. Dia beserta anaknya sering melakukan perjalanan keliling antar masjid pada malam hari. ${ }^{113}$ Sulaymān wafat di Basra pada tahun $143 \mathrm{H}$, bulan Zulqaiddah. ${ }^{114}$

\section{Abd' Al-Raḥmān bin Mulli bin 'Amru bin 'Adīy Ibnu Wahab bin Rabī'ah bin} Sa’ad bin Ḥuzaymah bin Ka'ab bin Rifā'ah Ibnu Mālik, dikenal dengan kunniyah Abū 'Uṡmān digelari sebagai al-Hindīy, al-Bașrīy, al-Kūfìy. ${ }^{115}$ Beliau memeluk Islam pada masa Nabi saw. ${ }^{116}$ Gurunya aadalah sebagai berikut ; 'Umar

110 'Abd al-Gaffār Sulaymān al-Bundārīy, Mausū'ah Rijal al-Kutub al-Tis'ah, Juz II, (Beyrūt: Dār al-Kutub al’Ilmiyah, t.th.), h. 95; Hajjāj bin Yūsuf al-Mazzi, Tahzib al-Kamāl, Juz 1, h. 540; Ibnu Ḥajar al-'Asqalānīy, Tahzīb, Juz IV, h. 201.

${ }^{111}$ Syamsuddīn Abīy 'Abdillāh Muḥammad bin Aḥmad bin Uṡmān bin Qīmāż, Tazhīb Tahzib alKamāl Fìy Asmā' al-Rijā, Jilid IV, (T.tp. al-Fārūq al-Ḥadīìah li al-Ṭib’ah wa al-Nasyr, 2003), h. 150.

112 Syamsuddīn Abīy 'Abdillāh Muḥammad bin Aḥmad bin Uṡmān bin Qīmāż, Tazhīb Tahzib, Jilid IV, h. 151.

113 Syamsuddīn Abīy 'Abdillāh Muḥammad bin Aḥmad bin Us̉mān bin Qīmāż, Tazhīb Tahzib, Jilid IV, h. 153.

114 Syamsuddīn Abīy 'Abdillāh Muḥammad bin Aḥmad bin Us̉mān bin Qīmāż, Tazhīb Tahzib, Jilid IV, h. 154.

115 ‘Abd al-Gaffār Sulaymān al-Bundārīy, Mausū'ah Rijal, Juz II, h. 448. VI, h. 57.

${ }^{116}$ Syamsuddīn Abīy 'Abdillāh Muḥammad bin Aḥmad bin Us̉mān bin Qīmāż, Tazhīb Tahzib, jilid 


\section{Subehan Khalik}

bin Khaț̣āb, 'Ali bin Abīy Ṭālib, Abū Żar, Ibnu Mas'ūd, Ṭalḥah, Abū Mūsā, 'Āisyah. ${ }^{117}$ Murid-muridnya sebagai berikut; Qatādah, Ayyūb, al-Jarīr al-Sa'̄̄d, Dāwud bin Abīy al-Hindīy, Āṣim al-Ahwāl ${ }^{118}$ Dalam kesehariannya, Abū Us̉mān dikenal sebagai figure yang telaten melaksanakan shalat pada malam hari dan pada siangnya melakukan puasa, sebagaimana yang diutarakan oleh Sulaymān alTaymīy. ${ }^{119}$ Menurut sebagian riwayat menyatakan bahwa Abū Us̉mān telah melaksanakan beberapakali ibadah haji dan telah melaksanakan ibadah umrah sebanyak 60 kali. ${ }^{120}$ Al-Mu'tamir bin Sulaymān figure ini telah melaksanakan shalat sampai ia sarapan pada pagi harinya. Bahkan dia memiliki rombongan sahabat terdiri para anak yatim yang senantiasa menunggu makanan dari Abū Uṡmān dan ketika Ia wafat maka para anak yatim tadi berkata; "telah pergi sahabatku"121 Ia Wafat pada tahun 95 H. sementara itu Ibnu Ma'̄in menyatakan bahwa Abū Uṡmān wafat pada tahun $100 \mathrm{H}$. Sebagian riwayat menyatakan bahwa Abū Uṡmān telah menyertai sahabat Nabi Salmān al-Fārisīy selama 12 tahun. ${ }^{122}$

6. 'Abd al-Raḥmān bin Abīy Bakr. Kunniyahnya adalah: Abū Muḥammad, Abū 'Abdillāh. Gelararannya: al-Taymīy, al-Quraysyīy. ${ }^{123}$ Nama lengkap nya adalah 'Abdullāh Ibn Abīy Quhāfah. Ia adalah saudara kandung dari 'Āisyah ra. Dia menyaksikan lansung perang Badar bersama kaum musyrikin kemudian VI, h. 57.

${ }^{117}$ Syamsuddīn Abīy ‘Abdillāh Muḥammad bin Aḥmad bin Uṡmān bin Qīmāż, Tazh̄̄b Tahzib, jilid VI, h. 57.

118 Syamsuddīn Abīy 'Abdillāh Muḥammad bin Aḥmad bin Us̉mān bin Qīmāż, Tazhīb Tahzib, jilid VI, h. 57.

${ }^{119}$ Syamsuddīn Abīy 'Abdillāh Muḥammad bin Aḥmad bin Us̉mān bin Qīmāż, Tazhīb Tahzib, jilid VI, h. 59.

${ }^{120}$ Syamsuddīn Abīy ‘Abdillāh Muḥammad bin Aḥmad bin Uṡmān bin Qīmāż, Tazh̄̄b Tahzib, jilid VI, h. 59

${ }^{121}$ Syamsuddīn Ab̄̄y 'Abdillāh Muḥammad bin Aḥmad bin Uṡmān bin Qīmāż, Tazhīb Tahzib, jilid VI, h. 59.

${ }^{122}$ Syamsuddīn Ab̄̄y 'Abdillāh Muḥammad bin Aḥmad bin Us̉mān bin Qīmāż, Tazhīb Tahzib, jilid

123 'Abd al-Gaffār Sulaymān al-Bundārīy, Mausū'ah Rijal al-Kutub al-Tis'ah, Juz II, h. 397 
menyatakan keislamannya dan ikut berhijrah bersama Rasulullah saw. sebelum fath Makkah. ${ }^{124}$ Sufyan bin Uyainah memberitakan dengan sanad yang berasal dari Ali bin Ziad bin Jud'ān bahwa 'Abd al-Raḥmān ikut serta dalam perang Yamāmah bersama Khalid bin Walid. Dalam perang tersebut ia membunuh tujuh orang pemuka perang dari kelompok musuh dan salah satunya adalah Panglima perang Yamāmah bernama Ibnu Țufayl. ${ }^{125}$

'Abd al-Raḥmān bin Abīy Bakr menerima riwayat lansung dari Rasulullah saw. dari Bapaknya Abū Bakr al-Ṣiddīq. ${ }^{126}$ Diantara murid-murid beliau adalah sebagai berikut: Sa'̄̄d bin Musayyab, Syuraih bin al-Hārisis al-Qāḍīy dan anaknya 'Abdullāh bin 'Abd al-Rahmān bin Abī Bakr al-Ṣiddīq, Abdullāh bin 'Ubaidillāh bin Ab̄̄ Mulaikah, 'Abdullāh bin Ka'ab, 'Abd al-Rahmān bin Abīy Laylīy, 'Amr bin Uways al-Ṣaqafìy, serta anak perempuannya Hafșah binti 'Abd al-Raḥmān bin Abīy Bakar al-Șiddīq. ${ }^{127}$ Para sahabat memberi penilaian dalam hal kepribadian kepada 'Abd al-Raḥmān bin Abīy Bakar al-Ṣiddīq sebagai figur yang saleh sebagaimana ungkapan dari Zubayr bin Bakkār. ${ }^{128}$ Ma'mar berkata dengan sanad yang disandarkan kepada al-Zuhri, dari Ibnu al-Musayyab dalam hadisnya yang menyebut bahwa 'Abd al-Raḥmān bin Abīy Bakar al-Șiddīiq; "Tidak pernah bersentuhan dengan kebohongan sesaat pun". ${ }^{129}$ Abū Zur'ah al-Damsyiqīy meriwayatkan bahwa 'Abd al-Raḥmān bin Abīy Bakar al-Șiddīq wafat ketika Mu'awiyah mengakhiri kunjungannya ke Madinah al-Munawwarah dalam rangka menerima bai'at dari 'Abdullāh bin 'Umar, 'Abdullāh bin Zubayr dan 'Abd alRaḥmān bin Abīy Bakar al-Ṣiddīq. ${ }^{130}$ Peristiwa ini beriringan dengan wafatnya

\footnotetext{
${ }^{124}$ Hajjāj bin Yūsuf al-Mazzi, Tahzib al-Kamāl, Juz 6, h. 555.

${ }^{125}$ Hajjāj bin Yūsuf al-Mazzi, Tahzib al-Kamāl, Juz 6, h. 556

${ }^{126}$ Hajjāj bin Yūsuf al-Mazzi, Tahzib al-Kamāl, Juz 6, h. 556

${ }^{127}$ Hajjāj bin Yūsuf al-Mazzi, Tahzib al-Kamāl, Juz 6, h. 557

${ }^{128}$ Hajjāj bin Yūsuf al-Mazzi, Tahzib al-Kamāl, Juz 6, h. 557

${ }^{129}$ Hajjāj bin Yūsuf al-Mazzi, Tahzib al-Kamāl, Juz 6, h. 557

${ }^{130}$ Hajjāj bin Yūsuf al-Mazzi, Tahzib al-Kamāl, Juz 6, h. 557
} 


\section{Subehan Khalik}

'Āisyah ra. Pada tahun 59 H. Namun riwayat menjelaskan bahwa 'Abd al-Raḥmān bin Abīy Bakar al-Ṣiddīq wafat pada tahun $55 \mathrm{H} .^{131}$

Sebuah hadis dapat dikatakan sahīh jika ia memiliki beberapa kriteria. Secara tegas kriteria ini diantaranya dikemukakan oleh Ibn Salah sebagai berikut:

1. Sanad Bersambung

2. Periwayat Bersifat Adil

3. Periwayat Bersifat Dabit

4. Dalam Hadis Tidak Terdapat Kejanggalan (syaz)

5. Dalam hadis tersebut tidak terdapat cacat ('illat). ${ }^{132}$

Untuk menyatakan sebuah hadis berkualitas sahīh dalam pengertian $s$ ॐँah li zātih, ia haruslah memenuhi target kesahihan dari segi sanad dan matan. ${ }^{133}$ Dengan demikian penelitian untuk menguji sahih sebuah hadis haruslah melewati proses penelitian sanad dan matan.

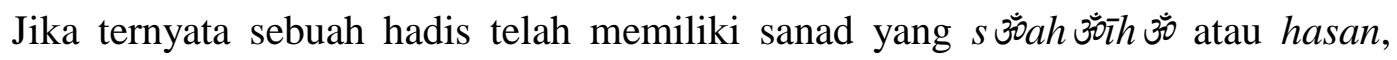
maka ia dapat diteliti matannya. Hal ini diperlukan untuk menguat kan posisi sebuah hadis agar dapat dijadikan sebagai hujjah. Sebuah hadis yang telah memenuhi kriteria kesahihan sanad, dapat dijadikan hujjah jika telah memenuhi kriteria kesahihan matan. ${ }^{134}$ Keterangan ini membenarkan bahwa kritik sanad mutlak diperlukan dalam pemanfaatan sebuah hadis menjadi hujjah. Ini pula yang mendasari pemikiran alNawāwīy untuk menganalogikan fungsi sanad terhadap hadis sebagai fungsi kaki terhadap binatang. ${ }^{135}$

${ }^{131}$ Hajjāj bin Yūsuf al-Mazzi, Tahzib al-Kamāl, Juz 6, h. 557

${ }^{132}$ Lihat Ibn Salah, 'Ulū̄m al-Hadīs (Muqaddimat Ibn Sālah), (Madinah al-Munawwarah: alMaktabah al-'Ilmiyah, 1972), h. 10.

${ }^{133}$ Lihat Salāh al-Dīn ibn Ahmad al-Adabiy, Manhaj al-Naqd al-Matn (Beirūt: Dar al-Āfāq alJadīdah, 1983 M.), h. 254.

${ }^{134}$ Lihat M. Syuhudi Ismail, Hadits Nabi Menurut Pembela Pengingkar dan Pemalsunya (Jakarta: Cet. II; Gema Insani Press, 1995), h. 81.

135 Imām al-Nawāwīy, Syarh Muslim li al-Imām al-Nawāwīy, Juz I (Mesir: Matba'at alMis ॐँ riyyah, 1924), h. 88. 
Untuk kepentingan penelitian matan, penulis menggunakan tiga langkah yaitu;

1. Meneliti matan dengan melihat kualitas sanad hadīs

2. Meneliti susunan lafal matan yang semakna

3. Meneliti kandungan matan. ${ }^{136}$

Dari ketiga metode yang dikemukakan, item pertama telah dilaksanakan. Selanjutnya, secara berturut-turut akan diteliti susunan lafal matan yang semakna dan kandungan matan.

Jika diamati secara seksama, lafal hadis yang diteliti memiliki kesamaan redaksional dengan hadis-hadis semisal dari periwayat lainnya. Hadis tentang perlakuan Rasulullah saw. terhadap penolakan hibah dari seekor kambing yang akan menjadi jamuan Rasulullah saw. kepada para sahabatnya. Hadis-hadis tentang hal ini telah diriwayatkan secara lafžiy. Dengan demikian, kuat dugaan bahwa hadis ini memiliki kriteria kesahihan yang cukup baik sebab telah terjadi persambungan sanad di antara para periwayat dan para periwayatnya tidak ada yang bermasalah. Dengan demikian hadis ini dapat dikategorisasi sebagai hadis yang dapat digunakan sebagai hujjah.

\section{Fiqh al-Hadis}

Hadis tentang hibah dan derifasinya sangat banyak dalam kitab-kitab hadis Sembilan. Secara garis besar hadis ini mengatur tentang beberapa aspek meliputi:

1. Hadis-hadis Nabi tentang perlakuan terhadap barang hibah

2. Azas keadilan dalam hibah serta mempersaksikannya

3. Larangan mengambil kembali hibah yang telah diberikan

4. Kepemilikan hibah (mahar) yang diserahkan sebelum pernikahan

5. Nabi tidak menerima hibah kecuali dari suku Quraisy, Anshar dan Saqif

6. Larangan membegal (merampas harta milik orang lain)

7. Anjuran Nabi untuk saling memberi hadiah

${ }^{136}$ M. Syuhudi Ismail, Metodologi Penelitian Hadis Nabi (Jakarta: Bulan Bintang, 1992 M.), h. $121-22$. 
Merupakan landasan yang jelas dalam melaksanakan perbuatan hukum ini. Dikatakan demikian sebab telah cukup alasan untuk menyatakan bahwa kehujjahan hadis-hadis tersebut dapat menjadi landasan hukum.

Menurut Ibnu Hajar al-`Asqalānīy, hadis tentang keterangan pemberi kejelasan terhadap status hibah merupakan bentuk lain dari jual-beli. Dalam kondisi penjual telah memberi keterangan bahwa kambing akan dijual dan bukan untuk dihibahkan. Hal ini merupakan penguat bahwa telah terjadi jual-beli antara Rasulullah saw. dengan orang musyrik meski sebelumnya terjadi Tanya jawab tentang eksistensi kambing tersebut. Meski sebelumnya orang musyrik tidak menyebutkan berapa harga dari kambingnya, namun ketika Rasulullah bertransaksi dengan orang musyrik tadi dalam koridor julabeli, maka terjadilah proses jual beli dalam kasus ini. Ibnu Hajar menambahkan bahwa kunci dari jual-beli adalah penguasaan seseorang terhadap benda yang telah dijadikan sebagai objek dan dalam kasus ini objek jual-beli kemudian berpindah ke tangan Rasulullah saw. ${ }^{137}$

Dalam konteks ini perlu penggarisan bahwa hibah tidak menghalangi seseorang untuk melaksanakan jual-beli atas objek yang akan dihibahkan. Berarti pula pelaku hibah sebelum melaksanakan proses hibahnya, dapat menjual objeknya tanpa melalui proses hibah tadi. Dan konteks inilah yang berlaku terhadap Rasulullah saw. ketika menanyakan status objek yang ternyata dijual oleh orang musyrik tadi.

Hadis lain yang membahas tentang hibah adalah larangan untuk mengambil hak orang lain secara paksa (begal dan rampok). Dalam kasus ini Rasulullah memberi penegasan secara jelas bahwa Ia tidak mentolerir perbuatan demikian dan memberi penegasan bahwa barang siapa yang berbuat demikian, maka sungguh orang tersebut telah keluar dari golongan Rasulullah saw.

Hadis lain tentang hibah berbicara tentang larangan mengambil kembali objek yang telah dihibahkan. Namun pada kondisi ini terdapat dispensasi yaitu hibah orang tua kepada anaknya. Hal demikian ini disepakati oleh ulama secara garis besar. ${ }^{138}$

\footnotetext{
${ }^{137}$ Ibnu Ḥajar al-‘Asqalānīy, Fatḥ al-Bāri, juz 4, (Beyrūt: Dār al-Kutub al’Ilmiyyah , t.th,), h. 336.

${ }^{138}$ Ibnu Hajar al-‘Asqalānīy, Fath al-Bāri, juz 4, h. 336.
} 


\section{Kesimpulan}

1. Setelah mengadakan penelitian dan kritik terhadap sanad dan matan hadis tentang hibah (kasus kambing yang kemudian dibeli oleh Rasulullah saw.) cukup alasan untuk menyatakan bahwa hadis tersebut berstatus șaḥh dan dapat kiranya dijadikan sebagai hujjah. Hadis ini memiliki struktur sanad yang apik dan pada periwayatan yang dikemukakan oleh Imam Muslim terdapat mutābi' pada tingkat periwayat ke 5 sanad kedua. Telah terjadi persambungan sanad dari guru ke murid dan lambing periwayatan yang digunakan meliputi haddasisanā, 'an dan qāla.

2. Rasulullah telah melaksanakan berbagai hal terhadap hibah diantaranya mengutuk orang yang mengambil kembali hibah mereka serta mengambil paksa hak orang lain. Pada sisi lain Rasulullah saw. juga memberi himbauan agar umatnya saling memberi hadiah dan memberi hibah. 


\section{Hibah Dalam Persfektif Sunnah Nabi}

\section{Subehan Khalik}

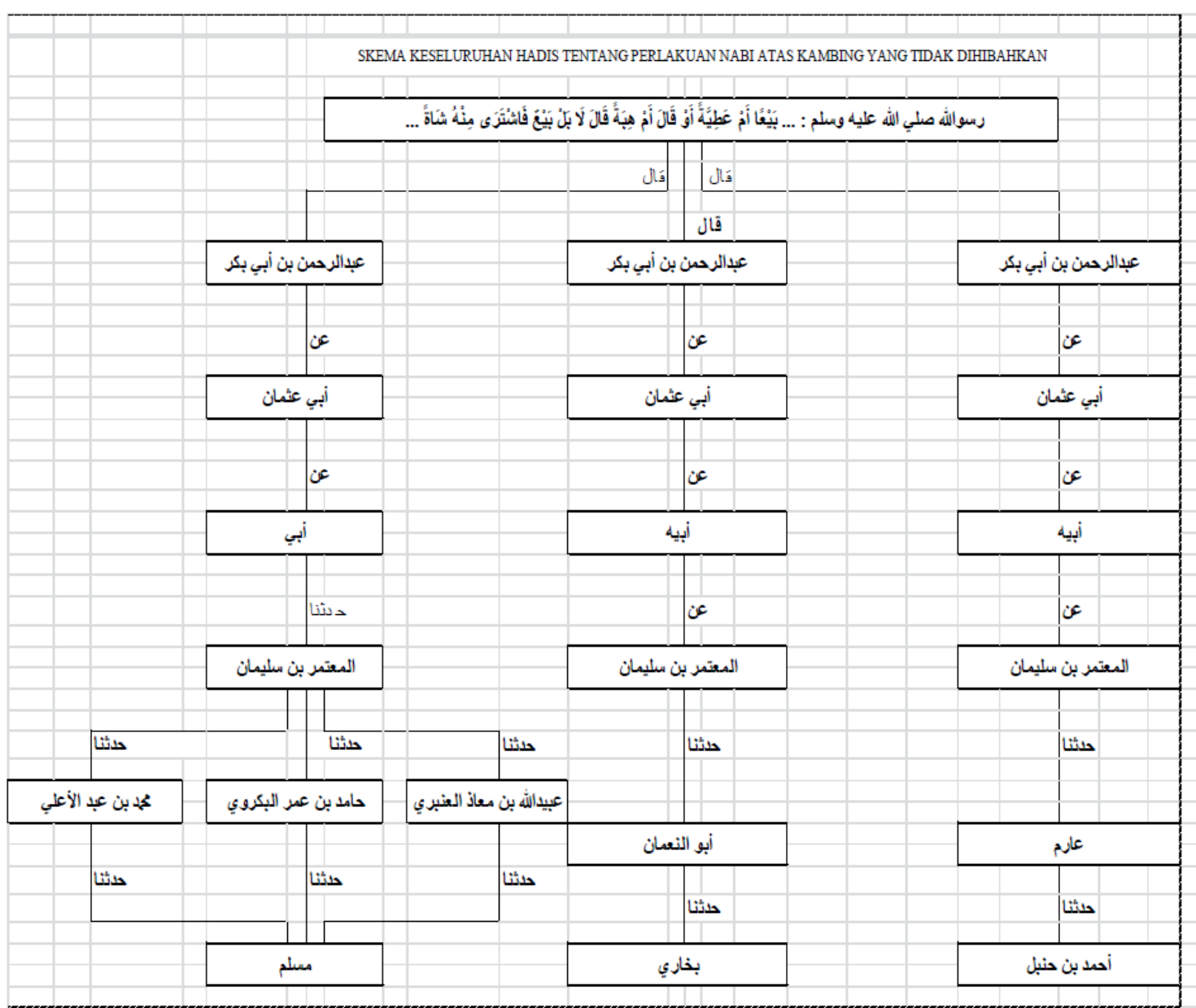




\section{DAFTAR PUSTAKA}

'Abd al-Bāqi; Muḥammad Fuā'd, Miftāḥ Kunūz al-Sunnah, (Lahore; Idārah Tajumān al-Sunnah, 1978),

'Abd al-Gaffār Sulaymān al-Bundārīy, Mausū'ah Rijal al-Kutub al-Tis'ah, Juz II, (Beyrūt: Dār al-Kutub al'Ilmiyah, t.th.),

Abī Muḥammad 'Abd al-Rahmān bin Abīy Ḥātim Muḥammad bin Idrīs bin Munzir alTamīymīy al-Hazalīy al-Rāzīy, Kitāb al-Jarh al-Ta'dīl, Jilid IV, (Beyrūt: Dār alKutub al-'Ilmiyyah, 1953)

Abū Bakr Aḥmad ibn 'Ali al-Khat ऊँōb al-Bagdādīy, Tārikh Bagdād aw Madīnat alSalām, juz IV (Al-Madinat al-Munawwarah: al-Maktabat al-Salafiyyah, t.th.)

Abu Muhammad Abdul Mahdi bin Abdul Qadir bin Abdul Hadi, Turuq Takhrij Hadis Rasulullah saw., diterjemahkan oleh H.S.Agil Husin Munawwar dan H.Ahmad Rifqi Muchtar, Metode Takhrij Hadits (Semarang: Cet. I; Dina Utama, 1994),

Abu al-Hasan `Ali ibn 'Umar ibn Aḥmad al-Dāraqutniy, Zikr Asmā' al-Tābi '̄n Wa Man

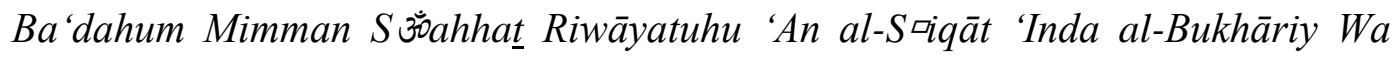
Muslim, juz I (Beirut: Mu'assasat al-Kutub al-Saqafiyyah, 1986 M.)

al-`Asqalaniy; Ibnu Hajr, Nuzhat al-Nazar Syarh Nukhbat al-Fikr (Kairo: Maṭba'at Istiqāmah, 1368 H.),

al-Syahrazūriy ; Abu `Amr 'Uṡmān ibn’ Abd al-Raḥmān ibn al-Șalah, 'Ulūm al-Hadis̀ (al-Madinat al-Munawwarah: al-Maktabat al-'Ilmiyyah,1972 M.),

Al-Zahabi, Kitab Tazkirat al-Huffaz, juz II (Beirut: Dar Ihya' al-Turas al-`Arabiy, 1375 H./1955 M.)

Hajjāj bin Yūsuf al-Mazzi, Tahzib al-Kamāl fi Asma' al-Rijal, Jilid V, (Beirūt: Mu'assah al-Risalah, 1997),

Ibn Salah, 'Ulū̄m al-Hadīs (Muqaddimat Ibn Sālah), (Madinah al-Munawwarah: alMaktabah al-'Ilmiyah, 1972),

Ibnu Hajar al-'Asqalānīy, Fatḥ al-Bāri, juz 4, (Beyrūt: Dār al-Kutub al'Ilmiyyah , t.th,) Ibrahim Dasuqiy al-Syahawiy, Mustalah al-Hadīs (Kairo: Syirkat al-Taba'at alFanniyyat al-Muttahidah, t.th.)

Imām al-Nawāwīy, Syarh Muslim li al-Imām al-Nawāwīy, Juz I (Mesir: Matba'at alMisriyyah, 1924), 
Ismail M. Syuhudi, Hadits Nabi Menurut Pembela Pengingkar dan Pemalsunya (Jakarta: Cet. II; Gema Insani Press, 1995) . Syuhudi, Metodologi Penelitian Hadis Nabi (Jakarta: Bulan Bintang, 1992 M.)

Syuhudi, Kaedah Kesahihan Sanad Hadis; Telaah Kritis dan Tinjauan dengan Pendekatan Ilmu Sejarah (Jakarta: Cet. I; Bulan Bintang, 1988)

Jalāl al-Din 'Abd al-Raḥman bin Abi Bakr al-Suyuṭ̂y, Tabaqat al-Huffāz (Beirut: Dar al-Kutub al-'Ilmiyyah, 1983 M.)

Muhammad 'Abdullāh al-Jardaniy, Fath al-'Allām bi Syarh Mursyid al- Anam fî Fiqh 'ala Mazhab al-Sadat al-Syafi iyah, Juz IV (al-Madinat al-Munawwarah: Dār alSalam li al-Tऊँiba'at wa al-Nasyr, 1990 M.)

Muhammad `Ajjaj al-Khatib, Usûl al-Hadîs `Ulumuhu wa Mustalahuhu (Beirut: Dar alFikr, 1409 H./1989 M.)

Muhammad al-Sabbag, al-Hadis al-Nabawiy (T.t.: al-Maktab al-Islamiy, 1392 H./ 1972 M.)

Salāh al-Dīn ibn Ahmad al-Adabiy, Manhaj al-Naqd al-Matn (Beirūt: Dar al-Āfāq alJadīdah, 1983 M.),

Sulaimān bin al-Asy‘ab al-Sijistānīy ; Abū Dāwud, Sunan Abī Dāwud, Juz III, (t.tp.; Muhammad 'Alīy al-Sayyid Nasyr wa al-Tauzi', t.th.),

Sunan Al-Turmūziy, Al-Jāmi' al-Ṣaḥīḥ, Juz V, (Beirūt: Dār al-Kutub al-'Ilmiyyat, t.th.), Syamsuddīn Abīy 'Abdillāh Muḥammad bin Aḥmad bin Us̉mān bin Qīmāż, Tazhīb Tahzib al-Kamāl Fìy Asmā' al-Rijāa, Jilid IV, (T.tp. al-Fārūq al-Ḥadīsah li alTib'ah wa al-Nasyr, 2003)

Syamsuddīn Abīy 'Abdillāh Muḥammad bin Aḥmad bin Us̉mān bin Qīmāż, Tazhīb Tahzib al-Kamāl Fìy Asmā' al-Rijā, Jilid IV, (T.tp. al-Fārūq al-Ḥadīsah li alȚib'ah wa al-Nasyr, 2003),

Ṭaḥhāan; Mahmūd, Taysir Musṭalah al-Hadīs. (Beirūt: Dār al-Qur'ān al-Karīm, 1979 M) 